\title{
Inhalation monoclonal antibody therapy: a new way to treat and manage respiratory infections
}

\author{
Hilal Ahmad Parray ${ }^{1}$ - Shivangi Shukla ${ }^{1} \cdot$ Reshma Perween $^{1} \cdot$ Ritika Khatri $^{1} \cdot$ Tripti Shrivastava $^{1} \cdot$ Vanshika Singh $^{1}$. \\ Praveenkumar Murugavelu ${ }^{1}$. Shubbir Ahmed ${ }^{1}$. Sweety Samal ${ }^{1}$. Chandresh Sharma ${ }^{1}$. Subrata Sinha ${ }^{2}$. \\ Kalpana Luthra ${ }^{2} \cdot$ Rajesh Kumar' $^{1}$ (1)
}

Received: 14 July 2021 / Revised: 14 July 2021 / Accepted: 30 July 2021 / Published online: 23 August 2021

(c) The Author(s), under exclusive licence to Springer-Verlag GmbH Germany, part of Springer Nature 2021

\begin{abstract}
The route of administration of a therapeutic agent has a substantial impact on its success. Therapeutic antibodies are usually administered systemically, either directly by intravenous route, or indirectly by intramuscular or subcutaneous injection. However, treatment of diseases contained within a specific tissue necessitates a better alternate route of administration for targeting localised infections. Inhalation is a promising non-invasive strategy for antibody delivery to treat respiratory maladies because it provides higher concentrations of antibody in the respiratory airways overcoming the constraints of entry through systemic circulation and uncertainity in the amount reaching the target tissue. The nasal drug delivery route is one of the extensively researched modes of administration, and nasal sprays for molecular drugs are deemed successful and are presently commercially marketed. This review highlights the current state and future prospects of inhaled therapies, with an emphasis on the use of monoclonal antibodies for the treatment of respiratory infections, as well as an overview of their importance, practical challenges, and clinical trial outcomes.
\end{abstract}

\section{Key points}

- Immunologic strategies for preventing mucosal transmission of respiratory pathogens.

- Mucosal-mediated immunoprophylaxis could play a major role in COVID-19 prevention.

- Applications of monoclonal antibodies in passive immunisation.

Keywords Therapeutic antibodies $\cdot$ Respiratory viral infections $\cdot$ Prophylactic $\cdot$ Intranasal $\cdot$ SARS-CoV-2 $\cdot$ Inhaled delivery

\section{Introduction}

Therapeutic antibodies offer valuable tools in the medical field for treating a variety of disorders and have emerged as one of the dominant therapeutic modalities, with over 50 approved

Hilal Ahmed Parray, Shivangi Shukla and Reshma Perween are equally contributed to this work.

Rajesh Kumar

rajesh@thsti.res.in

1 Translational Health Science \& Technology Institute, NCR Biotech Science Cluster, 3rd Milestone, Faridabad - Gurgaon Expressway, PO Box \# 04, Faridabad, Haryana 121001, India

2 Department of Biochemistry, All India Institute of Medical Sciences, New Delhi, India products and over 500 monoclonal antibody (mAb)-based therapies in clinical development (Parray et al. 2020b). mAbs are natural macromolecules that have a high affinity and specificity for binding to a wide range of antigenic targets by utilising unique pharmacokinetic (PK) and pharmacodynamic (PD) properties. Among the recently approved biologics, more than $90 \%$ were mAb-based drugs (Posner et al. 2019). This increasing success of mAbs can be attributed to their favourable safety, target specificity, and pharmacokinetics compared to traditional small-molecule drugs. There is no risk of the administered antibodies, in terms of getting metabolised in vivo into toxic metabolites, so, relative to small molecule drugs, the likelihood of therapeutic phase transition is very high. Antibody-based therapeutics have made significant improvements in autoimmune diseases, cancer bio-therapeutics, and patient survival rates with decreased side effects. However, limited success has been achieved in 
the case of viral targets. In recent years, immunotherapy has represented a potential intervention to mitigate virus spread and disease severity. A number of $\mathrm{mAbs}$ have been isolated from a variety of sources by utilising different strategies for therapeutics or preventive approaches against infectious viral diseases such as the human cytomegalovirus (Gerna et al. 2016), influenza (DiLillo et al. 2014; Tan et al. 2016; Biswas et al. 2020), human immunodeficiency virus (Kumar et al. 2012, 2018, 2019a; Khan et al. 2017), respiratory syncytial virus (Tang et al. 2019), SARS-CoV-2 (Pinto et al. 2020; Parray et al. 2020a; Schoof et al. 2020; Perween et al. 2021), Ebola (Flyak et al. 2018), Zika (Sapparapu et al. 2016), rabies (Kim et al. 2017), HBV (Hong et al. 2019), and dengue (Durham et al. 2019). Two of these mAbs are currently approved for the treatment of viral infections; palivizumab for the prevention of respiratory syncytial virus (RSV) infection in high-risk children (Olchanski et al. 2018); and ibalizumab has been introduced for the treatment of HIVinfected individuals who have acquired multidrug antiretroviral therapy (ART) resistance (Rizza et al. 2019). More recently, Inmazeb (atoltivimab, maftivimab, and odesivimab-ebgn), a mixture of three monoclonal antibodies, has been approved as the first FDA-approved treatment for adult and pediatric Zaire ebolavirus (Ebola virus) infection, opening a new avenue to explore more therapeutic mAbs for other viral infections (Markham 2021). Most of these therapeutic mAbs are typically administered intravenously (IV) or through a systemic passive immunisation strategy, although aerosol or subcutaneous delivery are preferred for some applications (Viola et al. 2018). One potential drawback of the systemic approach is the limited absorption of $\mathrm{mAbs}$ from the site of administration, via blood circulation, to the infected organs, that overall affects and limits therapeutic target access. Respiratory complications (caused by viral and non-viral agents, for example) primarily affects respiratory organs, limiting absorption of therapeutic mAbs assimilated via the systemic route (Guilleminault et al. 2014; Liang et al. 2020). However, researchers are exploring different alternative routes of therapeutic mAb administration to respiratory organs and one such potential approach might be using the mAbs through the inhaled route thereby overcoming such limitation (Fick et al. 2000). Passive administration of antibodies by an inhaled route can deliver protective levels of antibodies immediately and directly to the susceptible mucosal surface that is the primary route of infection entry. Inhalation may facilitate a more rapid onset of impact (within minutes to hours) on organs of the respiratory system compared to other routes of administration (days) because it is generally presumed that the concentration of a biomolecule at its site of action determines the potency (Borghardt et al. 2018). Recent advances in $\mathrm{mAb}$-based prevention strategies have allowed the development of a new era of inhaled mAb-based public health intervention strategies (Desoubeaux et al. 2016; Desoubeaux et al. 2016; Kumar et al. 2019b, 2020, 2020). Because most respiratory viral infections begin at the mucosal surfaces in the upper respiratory tract, mucosal delivery of antibodies is not only effective for protection but also for reducing virus spread. Besides, the viruses at the mucous surface can be trapped by antibodies, thereby preventing mobility and restricting their diffusion to the environment, and the trapped viruses in the mucus can be shed from the body through normal mucous secretions.

The inhaled route of therapeutic biologicals may be more advantageous, especially in the case of respiratory disorders or distress. Respiratory diseases constitute a major public health issue worldwide: four of them are among the ten most common causes of death (pneumonia, tuberculosis, lung cancer, and chronic obstructive pulmonary disease (COPD) (Garantziotis and Schwartz 2010). They also represent a major socioeconomic burden through disability, health-care costs, and loss of productivity. Acute respiratory viral tract infections are responsible for a substantial share of human diseases worldwide. Medical and therapeutic interventions against viral respiratory tract diseases include vaccination, treatment with antiviral drugs, and symptom-based disease treatments (Weltzin and Monath 1999). By July 2021, the COVID-19 pandemic had reached more than 200 countries in which more than 180 million people got infected, and the infection was transmitted from one person to another through air droplets of an infected person via coughing, sneezing, or physical touch of infected surfaces. The disease is highly contagious with a mortality rate of around $2-3 \%$. However, the data available suggests higher fatality rates in older age groups and medical workers dealing with the COVID-19 crisis (Petrosillo et al. 2020). Currently, many vaccine candidates are being produced, with many having completed late-stage clinical trials and being approved for vaccination in the battle against COVID-19. Improved hygiene and social distancing are the arsenals to contain this virus and reduce its spread. Given the magnitude of the crisis, immediate, novel alternative approaches are required to combat COVID-19 (Chen et al. 2020). However, passive antibody-based immunisation approaches represent feasible new tools. The prophylactic use of antibodies for intranasal administration or mucosal route can be potentially used as supportive therapy in the airways for the prevention of respiratory viral infections. In this review, we discuss the use of therapeutic antibodies as a potential measure to prevent respiratory illness. We have also highlighted the advantages, limitations, and potential applications of inhaled mAbs as compared to systemic therapy, with special reference to controlling disease spread, pathogenesis, and disease severity. Herein, we have addressed the important considerations, challenges, and future perspectives associated with the development of inhaled antibody-based approaches and prevention strategies. In particular, we have discussed the role of inhaled mAbs as a target therapy for viral targets. 


\section{Systemic versus inhalation route}

Therapeutic antibodies are administrated via systemic (via the intravenous route, intramuscular, or subcutaneous injection) and non-systemic (localised) routes. The most common route for the administration of mAb-based therapeutics is a systemic route and is well adapted for the targeting of disseminated ailments (Jones and Martino 2016). However, several studies have shown that systemic administration is not the sole optimal mode of delivery for all antibody-based therapeutics (Koleba and Ensom 2006; Hansel et al. 2010). The non-systemic routes involve localised use of therapeutic antibodies where antibodies are injected, either at or near the area of disease or injury, allowing direct diffusion of the antibody to the region of the target site where a therapeutic effect is expected (Jones and Martino 2016). Ranibizumab, used for the treatment of wet age-related macular degeneration, a disease of the eye, is the first monoclonal antibody approved for targeted localised therapy by the Federal Drug Administration (FDA) and is recommended to be administered by intravitreal injection once a month (Moreno et al. 2017). The other non-systemic routes that have potentially been explored in recent years are the fistula tract, localised subcutaneous, intratumoural, peritumoural, and intranasal delivery (Fig. 1). Detailed information about these nonsystemic routes (except the inhaled route) has been discussed in different review articles (Schweizer et al. 2014; Jones and Martino 2016; Bodier-Montagutelli et al. 2017).

The inhalation route for administering therapeutic reagents is often used to treat lung conditions such as asthma or chronic obstructive pulmonary disease, by prescribing medications in the form of inhalants. Inhalation provides a variety

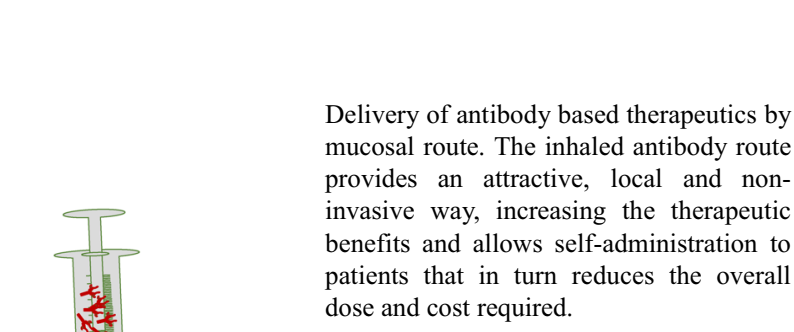

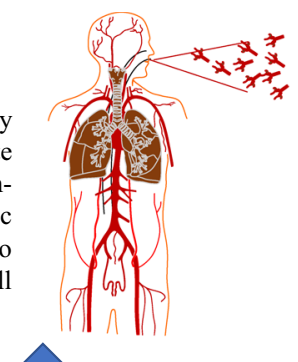

Intra nasal route

\section{Intradermal route}

Local delivery routes for therapeutic antibodies at a target site.. Antibodies may be injected locally in small volumes $(0.1 \mathrm{ml})$ via the intradermal route.

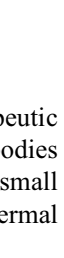

\section{DRo}

Delivery of antibody based therapeutics by patients that in turn reduces the overall

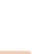

id
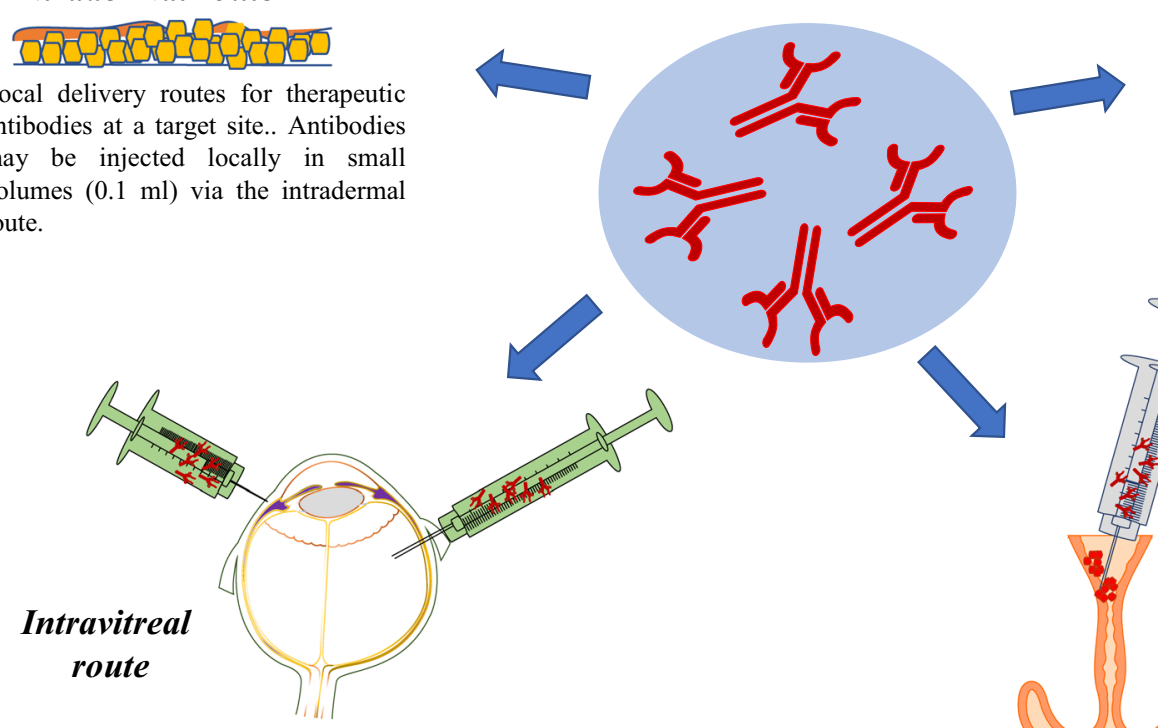

Intravitreal injections, into the vitreous humor of an eye. Subconjunctival injections typically antibody injected between the conjunctiva and the sclera while topical application may consist of antibody drops applied 2-6 times per day to the eye.

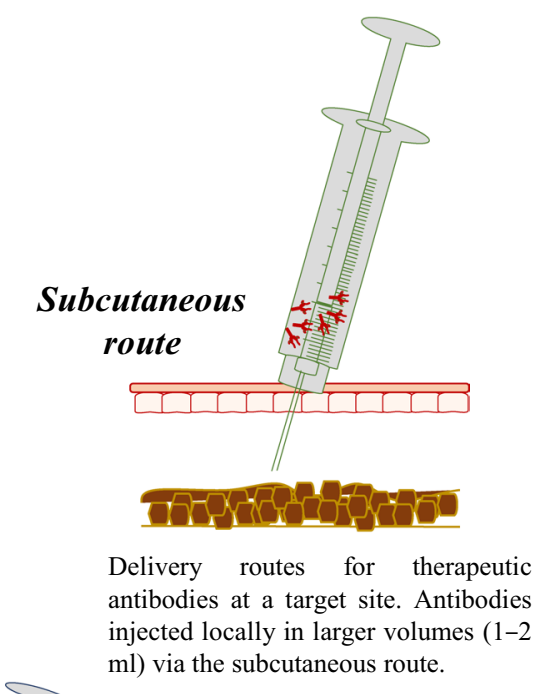

Fig. 1 Simplified schematic representation of non-systemic treatment routes. Overview of the local non-systemic delivery routes such as nasal, intradermal, subcutaneous, subconjunctival, intravitreal, and fistula tract antibody routes 
of benefits in the treatment of these respiratory diseases compared to other routes of administration, by reducing pulmonary symptoms like prevention of airway inflammation and constriction. In respiratory illnesses, the respiratory track is the main affected area where the disease spreads to other parts of the respiratory system. Targeted delivery of $\mathrm{mAbs}$ to the lungs through the systemic route results in very low $\mathrm{mAb}$ concentrations in the lungs, thus exposing the rest of the body to possible therapeutic side effects, including toxicity and cytokine release syndrome (Respaud et al. 2015; Burgess et al. 2018). For example, bevacizumab (Avastin) is a monoclonal antibody that blocks the growth of tumour blood vessels by targeting a protein called VEGF. It is used for the treatment of various cancers, and its delivery through systemic routes results in side effects such as high blood pressure, bleeding, blood clots, slow wound healing, and kidney damage (Li and Kroetz 2018). As a result, the inhaled route is a more appealing, local, and non-invasive alternative to the systemic route for such deliveries, permitting usage for the treatemnet of different types of cancers, while avoiding potential side effects (Abbas et al. 2019; Somasundaram et al. 2020). Furthermore, inhalant therapy allows patients to self-administer or be treated at a nursing home, thereby reducing the overall dose and cost requirements (Fahy et al. 1999; Cruz-Teran et al. 2021). Evaluation of the effectiveness of aerosol delivery of anti-tumour mAbs in lung cancer mouse models revealed that mAbs administered through the airway-inhaled route met their target antigen in the tumour at concentrations twice those achieved after intravenous delivery and are pharmacologically effective in limiting tumour development (Hervé et al. 2014). Furthermore, the pharmacokinetics of various mAbs administered through the airways in mice and non-human primates (NHPs) revealed small lung-to-bloodstream passage and antibody accumulation in the lungs (Bodier-Montagutelli et al. 2017). Similarly, preclinical studies of inhaled anti-IL-13 Fab' fragments have shown promising results in animal models of asthma in terms of reducing airway inflammation and hyperresponsiveness (Hacha et al. 2012).

Development of inhalation-based antibody treatment for humans is underway for various respiratory diseases, and early clinical studies have confirmed that it is an effective and safe approach to prevent respiratory tract diseases (Leyva-Grado et al. 2015; Van Heeke et al. 2017). Administration of anti-influenza virus broadly neutralising antibodies (bnAbs) through intranasal and aerosol routes showed higher prophylactic protection as compared to systemic routes and controlled the advanced stage infection with a much reduced dose of the administrated bnAb (Hart et al. 2001; Ibañez et al. 2011). (Fig. 2a). In comparison to parenteral treatment, inhalation of Abs gave better protection and greater therapeutic response in pneumonia models using influenza virus (Leyva-Grado et al. 2015).

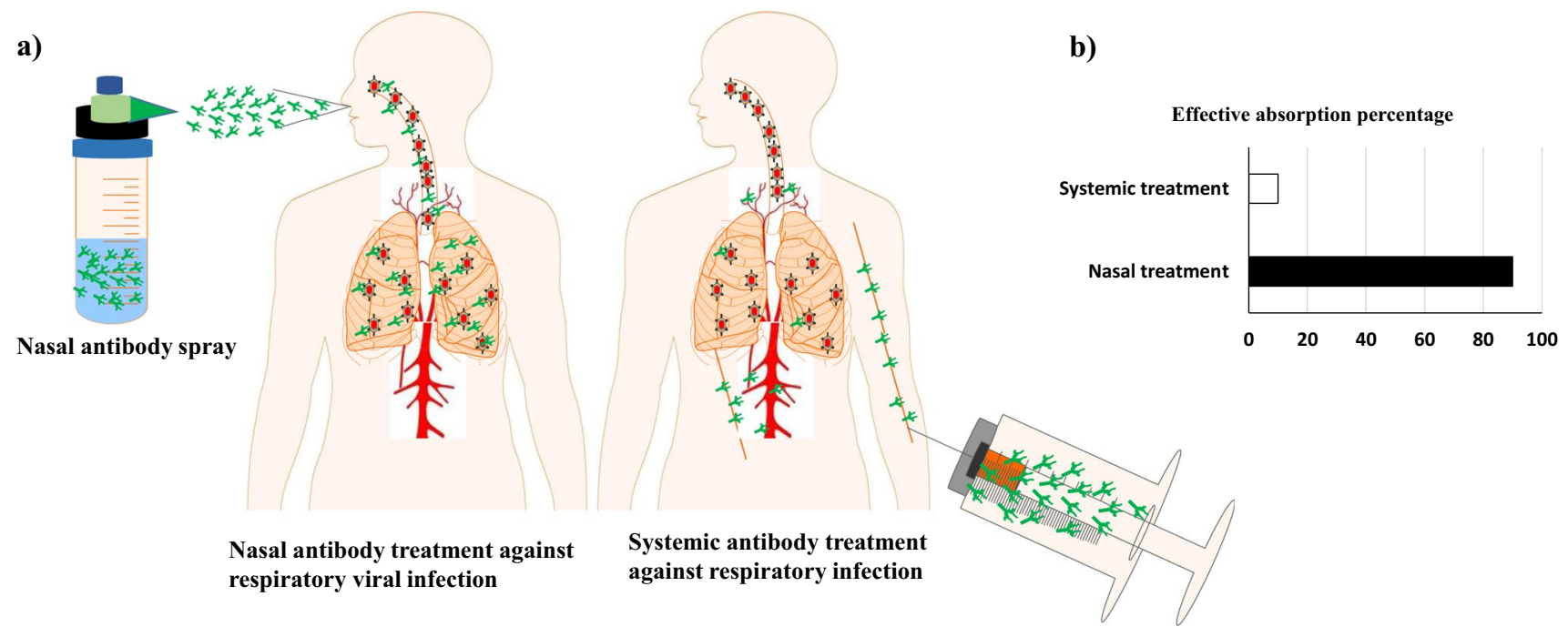

Fig. 2 Schematic representation of the antibody-based prevention strategies for respiratory infections. a The delivery of antibody-based therapeutics by mucosal route. The inhaled antibody route provides an attractive, local, and non-invasive way. It increases the therapeutic benefits and allows self-administration to patients that in turn reduces the overall dose and cost required. The mAbs in lungs by systemic route results in very low concentrations of the mAbs in the lungs, and exposing the rest of the body to potential adverse effects such as, toxicity, thickening of serum, and cytokine release syndrome. Delivering
mAbs by inhaled route will not only neutralise virulence of respiratory virus outbreak as well as will provide protection and a unique preventive strategy. b The dose of mAbs needed at mucosal surfaces is substantially low to treat an established proliferating infection as compared to systematic or intravenous route (Bodier-Montagutelli et al. 2017; Zhang et al. 2020). The delivery of mAbs in lungs by systemic route results in very low absorption concentrations of the mAbs in the lungs $(\sim 10 \%)$ as compared to mucosal route $(\sim 90 \%)$ 
Inhaled delivery of therapeutics against viral infections might evolve as a game changer. The intranasal presence of mAbs will have a better success rate in preventing the virus from getting a foothold to establish infection, thereby conferring protection and a unique prevention strategy during an emergency respiratory virus outbreak pandemic (Leyva-Grado et al. 2015; Abbas et al. 2019). The delivery of antibodies by the inhalant route will facilitate early stage contact with the pathogen in the respiratory tract, wherein the airborne infections originate and spreads. Thus, even a low concentration of the antibodies at the site of infection could potentially be effective in virus neutralisation (Fig. 2b) and overcome poor distribution of the antibodies, observed when using a systemic route, due to low expression of neonatal $\mathrm{Fc}$ receptor $(\mathrm{FcRn})$ in epithelial cells of the upper airways and alveolar macrophages in all species (Sakagami et al. 2006; Bequignon et al. 2019; Eichhoff et al. 2019). Figure 3 depicts a schematic description of antibody-mediated protection.

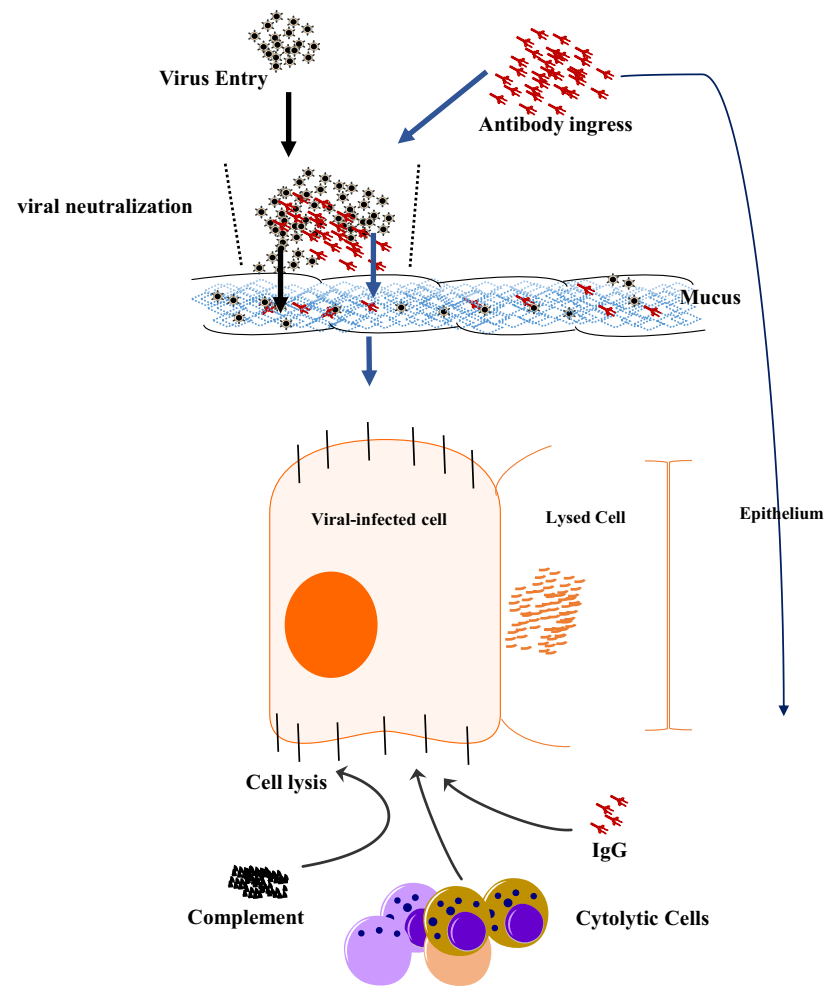

Fig. 3 Diagrammatic representation of the antibody-mediated protection from respiratory tract viral infection. Neutralising antibodies delivered to mucosal surfaces protects via two different mechanisms: (i) direct neutralisation of the free virus particles, which prevents virus from reaching host target cells and prevents virus from establishing infection and, secondly, via (ii) immune exclusion, antibodies can bind to virus-infected cells that are eliminated via antibodydependent cellular cytotoxicity and cytolytic T cell activity

\section{Choice and constraints of drug delivery device}

The inhalation route is mostly investigated for small molecular drugs and is underutilised for protein biotherapeutics due to a lack of supportive clinical data demonstrating its efficacy and the constraints associated with the inhaled protein production (Mayor et al. 2021). A successful inhaled administration of a biotherapeutic requires a harmonious relationship between the formulation, the inhaler device, and the patient. The device must be linked to deposit a pharmacologically active and safe mAb in the lung region of interest, efficiently and consistently. There are a variety of inhalation devices that are delivered directly to the airways. The three most commonly used inhalation devices are nebulisers, dry powder inhalers (DPIs), and metered-dose inhalers (MDIs) (MoroniZentgraf et al. 2018).

Nebulisers (jet, ultrasonic, and mesh) use a liquid solution of the medicine to produce aerosol droplets and are used to deliver them to the lungs and airways. Because the production process for nebulised formulations does not include additional drying procedures, they are less expensive to make and test. However, the suitability of nebulisers for the protein molecule is less favourable because prolonged storage of proteins in liquid solutions can result in protein instability and conformational changes via degradation pathways (i.e. deamination and hydrolysis), temperature, $\mathrm{pH}$ changes, and aggregation (via aqueous carrier agitation) (Kane et al. 2013; Respaud et al. 2014). A study conducted by Respaud et al. (2014) shows that the use of surfactants in antibody formulations considerably minimise aggregation formation during aerosolisation in mesh nebulisation. Human immunoglobulin preparations were successfully deposited into the conducting airways as well as the alveoli of treated lungs when nebulised with an eFlow ${ }^{\circledR}$ nebuliser in both rat and NHP studies (Vonarburg et al. 2019).

DPIs are propellant-free, portable, and simple-to-use inhalation devices that deliver medication in the form of a dry powder to the lungs. DPIs deliver drugs as a solid aerosol, whereas powder formulations have inherent stability and shelf life advantages. They do not necessitate cold chain storage or the reconstitution of powders into nebulisation solutions. Spray drying is a new technique for processing antibody dry particles. Pure antibody solutions, on the other hand, have been demonstrated to significantly agglomerate during this process (Faghihi et al. 2017). Such destabilisation is rationally linked to shearing stress in the nozzle, heat stress during drying, and surface adsorption of contaminants. Excipients such as trehalose and Tween 20 are used to protect proteins from 
disintegration during the spray-drying process (Cleland and Jones 1996). Trehalose has a high glass transition temperature, low hygroscopicity, and great water replacement efficacy, making it one of the most promising inhibitors of antibody aggregation. The surfactants like Tween 20 have also been demonstrated to compete with protein molecules at the air-liquid interface, preventing protein unfolding and aggregation (Mumenthaler et al. 1994; Jayasundera et al. 2011). The recent phase 1 double-blind, randomised research of inhaled interleukin-13 monoclonal antibody supports the development of inhaled antibodies as a viable future therapy option for parenteral mAbs. Single and repeat doses of dry powder anti-IL-13 fragment antibody provided through inhalation were shown to be well tolerated over up to 10 days (Burgess et al. 2018). Inhaled dry-powder COVID-19 antibodies are being developed by biotechnology companies to treat COVID-19 infections for inhalation into the lungs and are in early-stage clinical trials.

The MDI is a device that delivers a particular amount of medication to the lungs in the form of a short burst of a reliable, consistent dose of aerosolised drug, which is often self-administered by the patient by inhalation. Propellers are used in pMDIs to create aerosols for inhalation (Ibrahim et al. 2015). There is currently no approved pMDI product for inhaled biologics therapy. Proteins and peptides are generally hydrophilic, making them insoluble in non-polar propellants (Liao et al. 2005). The inability of biologics to dissolve in propellants limits the dose range that can be supplied per actuation (Fathe et al. 2016; Liang et al. 2020).

\section{Inhalation antibody prophylaxis for protection against respiratory infections}

Respiratory viruses that infect humans enter the body through the respiratory route, as aerosols formed by coughing or sneezing from other infected hosts. Large aerosol particles are typically trapped in the nasal turbinates and sinuses, where they can cause upper respiratory tract (URT) infections. Smaller particles in the lower respiratory tract can enter and cause infections in the alveolar areas with a higher mortality rate in respiratory diseases. Most of the viruses infecting URT cause an acute infection and infect humans seasonally (e.g. RSV, rhinovirus, parainfluenza, influenza A, adenovirus, human metapneumovirus, human bocavirus, and coronavirus). The most common syndromes caused by URT viruses are bronchiolitis and pneumonia (Manjarrez-Zavala et al. 2013). The epithelial cells of the mucosal surfaces are the first port of entry in most respiratory viral infections. The virus will not be able to establish an infection if the virus attachment is blocked at the point of entry. Antiviral agents, such as antibodies, have proven to be effective in preventing virus attachment and establishing infection. For example, the recent development of llama antibody-based strategies gives broad coverage of all the seasonal strains of the influenza virus, providing better hope for the development of future antibody-based strategies against influenza. Due to being smaller in size and shape as a part of their nature, llama antibodies can bind to cryptic epitopes that are not accessible through conventional antibodies (Harmsen and De Haard 2007). To date, no conventional mAb has been isolated that has the breadth and potency to neutralise all strains of influenza, A and B viruses. However, the isolated llama antibodies were effective against the multitude of influenza A and B viruses infecting humans (Cohen 2018). The nasal spray, containing a recombinant adeno-associated virus (AAV) vector engineered to express a protein derived from llama antibodies, showed protection in mice studies conducted against all known strains of flu viruses infecting humans and preventing them from further multiplying (Eichhoff et al. 2019).

Palivizumab is a humanised anti-RSV mAb used to reduce the risk of hospitalisation by $55 \%$ when given intramuscularly (IM). In a recent study related to RSV, it has been demonstrated that topical application of this $\mathrm{mAb}$ was approximately 100 times more effective than systemic delivery. In preclinical animal studies, inhaled antibody delivery in RSV (Gomi et al. 2018) and influenza has been shown to be effective (Ye et al. 2010). Similarly, a study conducted by Schepens et al. showed that VHHb nanobodies delivered intranasally, block viral infection as effectively as those administrated before infection (Van Heeke et al. 2017). The use of bnAbs as an alternative therapy for influenza virus-infected patients via the intranasal or aerosol route significantly decreases the amount of $\mathrm{mAb}$ required for protection by $1 \log$ compared with the administration via the intraperitoneal or intravenous route with a higher survival rate (Soto et al. 2020). Scientists have developed a rhesus monkey model of RSV infection and the studies based on the same have shown that the virus inoculum was directed to the upper airways only, whereas subsequent viral shedding was observed from both upper and lower respiratory tract secretions (Grandin et al. 2016). Grandin et al. (2015) created a Cynomolgus macaque model of mild infection using human RSV (hRSV), a common respiratory virus that causes infection in premature infants and children and is associated with high mortality when combined with other chronic diseases. This study showed that virological, clinical, and immunological parameters were also influenced by age and co-infection or morbidity (Grandin et al. 2015). Earlier animal studies have demonstrated that serum antibodies having high neutralising activity against the respiratory syncytial virus (RSV) can provide important prophylactic and therapeutic benefits when delivered either systemically (Prince et al. 1985; Hemming et al. 1985) or by topical instillation 
(by drops) into the airway (Prince et al. 1987; Hemming et al. 1988). Similarly, Weltzin et al. (1996) also showed that intranasal treatment with HNK20, a mouse IgA mAb (against RSV F glycoprotein) reduces upper and lower respiratory tract infection in rhesus monkeys. Because of their particular structure and glycosylation pattern, IgA antibodies may bind to mucins in the airway epithelium, extending their half-lives in the mucosa ( $\mathrm{Li}$ et al. 2020). In mice and nonhuman primates, prophylaxis of immunocytokines (e.g. IL-7 Fc) has demonstrated improved efficacy against airborne lethal viruses for several weeks via transcytosis in the lung tissues, leading to recruitment of $\mathrm{T}$ cells from circulation and their subsequent residency as tissue-resident memory-like $\mathrm{T}$ (TRM-like) cells (Kang et al. 2015). In contrast, limiting the response of pleiotropic molecules (e.g. IL-7 Fc), which are envisioned as adjuvant molecules, to the site of action may lessen systemic side-effects and allow for increased efficacy with a lower dose (Leyva-Grado et al. 2015; Sécher et al. 2019).

Another potential area, where researchers are exploring the fate of the development of chicken immunoglobulin (IgY)-based nasal spray as an effective prevention strategy against respiratory viral infections, is under development (Abbas et al. 2019). IgY is similar to human IgG and is present in both sera and the egg yolk of chickens. IgY antibodies do not react with the human $\mathrm{Fc}$ receptor and rheumatoid factor present on the cell surface, hence eliminating the risk of complement activation (Kovacs-Nolan and Mine 2012; Somasundaram et al. 2020). The IgY antibodies have three to five times more affinity for their target antigens, while IgG helps in faster reactivity of these antibodies to invading pathogens (Stuart et al. 1988; Lemamy et al. 1999; Rahman et al. 2013). IgY antibodies are well tolerated by the human system as eggs are a part of routine diet in humans (Abbas et al. 2019; Pérez de la Lastra et al. 2020). These differences provide great advantages for the successful application of IgY to humans as an alternative. Additionally, IgY antibodies are functional at a $\mathrm{pH}$ ranging from 4 to 9 and are stable up to $65^{\circ} \mathrm{C}$. The high content of sialic acid in IgYs increases the half-life of these Abs (Abbas et al. 2019). The prophylactic use of IgY Abs for intranasal administration could be potentially used in the airways for the prevention of viral infections. IgY Abs have shown greater binding affinity and neutralising activity against various bacterial and viral infections in humans and animals (Somasundaram et al. 2020). In vivo studies have shown that intranasal treatment of mice with virus-specific IgY before or after influenza B virus infection has a protective effect by minimising viral replication in the lungs (Wen et al. 2012). In a related study, when intranasal $\operatorname{Ig} \mathrm{Y}$ is administered $1 \mathrm{~h}$ before infection, $100 \%$ of mice are protected against lethal challenge by $\mathrm{H} 5 \mathrm{~N} 1$. The use of IgY Abs over IgGs in nasal spray provides several advantages, such as cost-effectiveness, convenience, and high doses of administration due to the lack of FcRn interactions (Li et al. 2015). The safety of intranasal IgY delivery has been successfully proved as a better treatment option for acute and chronic pharyngitis in humans (Xie et al. 2004). Studies have shown that the IgY antibody derived from chicken yolks is effective in neutralising severe acute respiratory syndrome (SARS) (Fu et al. 2006) and cystic fibrosis (Nilsson et al. 2008). Some of the leading pharmaceutical companies are exploring the fate of the IgY-based nasal spray for SARS-CoV-2 prevention.

Filoviruses, including Ebola, has the potential to be transmitted via virus-laden droplets deposited on the mucus membranes. Recent studies conducted using ZMapp, a cocktail of Ebola-neutralising mAbs in mice, have suggested that topical delivery of ZMapp to the mouse airways facilitates the rapid elimination of Ebola pseudovirus (Yang et al. 2018). These results suggest that in mucosal delivery, the antibody requirement would be many times less as compared to systemically delivered preparations, making it more costeffective. One of the major challenges that impedes the progress of many antiviral mAbs is the potentially higher cost associated with the production of recombinant antibodies, as compared to small molecule antivirals. Intranasal or mucosal delivery of mAbs can overcome this challenge, though more studies are needed to support the hypothesis.

\section{Inhaled delivery in special context to SARS-CoV-2, as a future prospective}

There are 66 vaccine candidates for COVID-19 in clinical trials as of February 2021 (Mullard 2020). Many COVID19 vaccines have demonstrated the effectiveness of up to $95 \%$ in phase III trials. The recent emergence of SARS-CoV-2 variants has raised concern about the effectiveness of the current vaccines against the mutant strains. In January 2021, variants began to be reported from the USA, France, Italy, Denmark, and others (Fontanet et al. 2021).

One potential alternative strategy for combating respiratory viral infections is to prevent viral entry before it spreads throughout the body. During early infection, the viral load on the mucus membrane surface is likely to be low. Treatment with a low dose of mAb during early mucous infections could substantially neutralise the virus from further spread (Leyva-Grado et al. 2015). Consequently, the delivery of therapeutic antibodies could be useful as a preventative measure in an emergency. The antibodies required to trap the virions on the mucus surface do not need to be neutralised. Aggregation or agglutination by antibodies may allow more efficient entrapment of virus in mucous and subsequent clearance, which greatly expands the potential of antibody-based methods for protection (Forthal 2014). Secondly, antibodies directed against host cell receptors can 
be used to target pathogens to block their receptor-mediated attachment to mucosal cells. Owing to their low molecular size, antibodies diffuse largely unimpeded into human mucus, where the Fc region of the antibody induces low affinity adhesive interactions with mucus mesh that prompts multivalent antibody interactions to capture the pathogen, stopping it from entering the underlying tissue (Saltzman et al. 1994; Olmsted et al. 2001). The two potential drawbacks that potentiate the requirement for inhaled antibody administration for respiratory infections are, first and foremost, a minuscule amount of mAbs reaching the lungs and large bronchoalveolar-lavage (BAL) space. Second, most of the medications that treat respiratory diseases work in the organs of the respiratory system rather than in the periphery (Labiris and Dolovich 2003). The development of nasal spray treatments for SARS-CoV-2 is underway, and early clinical studies have confirmed that this approach is safe and can be used to prevent respiratory spread of SARS-CoV-2 (Westover et al. 2020; Zhang et al. 2020). Inhaled antibodies have the potential to be employed as a treatment, particularly for individuals who are not hospitalised and have a lower pathogen load. However, in some cases, antibodies might be provided as a prophylactic strategy. Pharmaceutical companies are making several efforts to develop antibody-based prophylactic sprays to create a durable antibody barrier in the nasal cavity to catch, bind, and neutralise the SARS$\mathrm{CoV}-2$ virus before it can reach and enter the cells that cause infection. The preclinical COVID-19-inhaled mAb study demonstrates the therapeutic efficacy of these inhaled antibody reagents in animal models, with an average effective adult human dose of between 1 and $3 \mathrm{mg}$ (Piepenbrink et al. 2021). Prabakaran et al. (2009) have reported that passive transfer of neutralising serum antibodies through the intranasal route in a challenge experiment, prevented virus replication in the lower respiratory tract of naïve mice. Elevation of interleukin-6 (IL-6) is one of the chronic clinical symptoms in COVID-19-infected patients. Researchers are exploring using Foralumab to treat COVID-19 patients with lung damage and elevated IL-6 levels. Foralumab is a fully human anti-cluster definition 3 monoclonal antibody (anti-CD3 $\mathrm{mAb}$ ) that binds to the $\mathrm{CD} 3$ epsilon unit of the IL-6 receptor. Binding of this $\mathrm{mAb}$ to the IL-6 receptor reduces its excessive level in the blood (Schoof et al. 2020). Elevated IL-6 levels drive chronic inflammation and is associated with severe lung damage (Mojtabavi et al. 2020). To evaluate the safety and tolerability, a phase 1 clinical trial has recently started in healthy volunteers using a nasally administered dose regimen with a nasal spray device. The inhaled administration of Foralumab induces disease-modifying Treg cells in the cervical lymph node to cross the blood-brain barrier and provide an anti-inflammatory signal via an IL-10-dependent pathway to downregulate the activated glial cells in the brain and help in maintaining homeostasis (Ogura et al.
2017; Ilan et al. 2018). Some of the studies conducted on inhaled delivery of mAbs are detailed in Table 1.

\section{Challenges and advancements associated with antibody-based prevention and therapeutic approaches for inhaled delivery}

Respiratory infections can be fatal. Therapeutic antibodies have the potential to confer protection against emerging viral infections, before a vaccine is developed. The appropriate route of administration of the antibodies is crucial for a favourable outcome. The major challenge that arises with mucosal delivery of mAbs comes from their frequent dosing and the short half-life of nasal antibodies. The concentration of active $\mathrm{mAb}$ in the lungs relies on the interplay of multiple pulmonary kinetic mechanisms, including the physicochemical properties of the mAb, its composition, and the device for inhalation as well (Ibrahim et al. 2015). Additionally, patient features, such as inhalation abilities, may also impair pulmonary effectiveness. The mucosal airway environment with continuous secretion and elimination of mucus coating likely necessitates at least once-a-day delivery to ensure adequate concentrations of mucosal Abs. Secondary infections (such as bacterial infections) and other pathological disorders (such as chronic sinusitis, COPD and cystic fibrosis $(\mathrm{CF})$ ) can potentially reduce the therapeutic efficacy of antibodies by thickening the mucus. The mucus in CF has a higher density of disulphide cross-links, which tightens the mucus mesh space even more, lowering the overall efficiency of the treatment (Yuan et al. 2015; Sécher et al. 2019). Higher concentrations of therapeutic biomolecules delivered in large quantities can have a detrimental influence on drug absorption owing to local adverse effects and, in certain circumstances, can damage the nasal mucosa. As a result, it is critical to recognise that the nasal cavity has limited capacity and that the dosage for nasal administration must be relatively modest (Ross et al. 2004). These limitations has been tried to overcome by improving mucosal delivery methods. Recent advancements in treatment with $\mathrm{a} \mathrm{mAb}$ via the aerosol route have significantly decreased the amount of antibody required for protection as compared with its administration via the systemic route (Maillet et al. 2011; Leyva-Grado et al. 2015). The other alternative method that has shown tremendous success is the use of engineered antibodies as a DNA delivery method. The engineered antibody gene can be directly delivered to nasal cells using a viral vector-based system, leading to the expression of antibodies and avoiding the continuous need for antibody dosing (Patel et al. 2020). This gene-based antibody delivery method is beneficial and safe for administration in the 


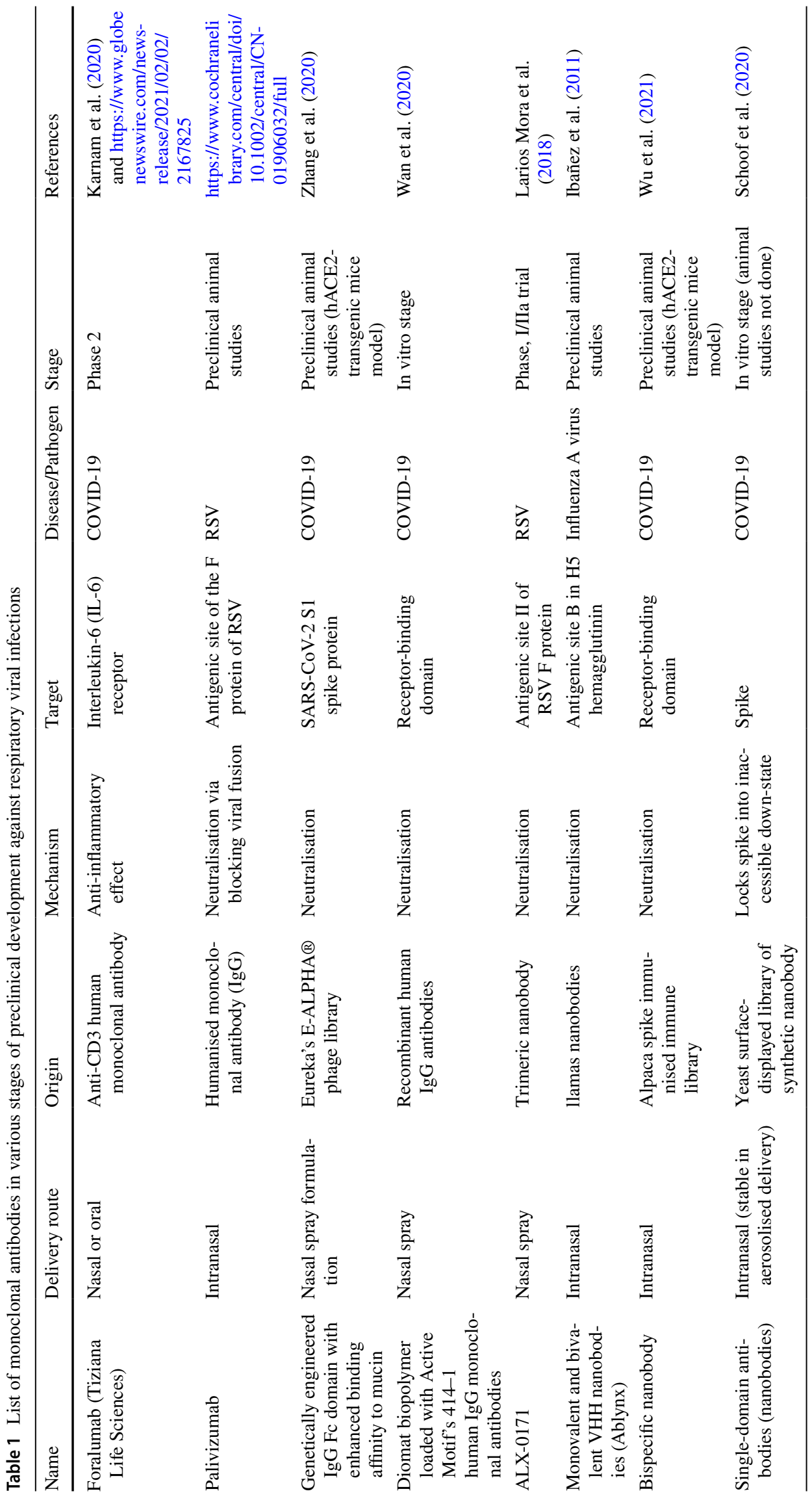


high-risk population, which includes immunocompromised hosts, pregnant women, etc. (Hollevoet and Declerck 2017).

The AAV and AdV are the most widely used vectors for gene delivery vehicles, but a substantial fraction of the human population has active antibodies to AAV2 (32\%) and AdV (55\%) (Chirmule et al. 1999), which can improve the adhesive trapping of these viral vectors in mucus mesh and inactivate their ability to transduce target cells. Additionally, nAbs to AAV1, AAV2, AAV5, AAV6, AAV7, and AAV8 are also present in the airways of healthy individuals (Halbert et al. 2006; Calcedo et al. 2009). Repeated dosing of these gene delivery vectors may lead to increased levels of nAbs to AAV and AdV, thus hampering the overall effect (Kim et al. 2016). ALX-0171 (Ablynx) is a trimeric nanobody, composed of three identical antibody domains linked end to end by flexible peptides that bind epitopes in the antigenic site II of the RSV F protein (Detalle et al. 2016; Larios Mora et al. 2018). The trivalent nanobody has shown better breadth and potency than the already marketed antibody palivizumab for RSV A and B strains. The ALX-0171 was given by nebulisation through a face-mask thus depositing in the upper and lower airways, showed faster and highly potent antiviral therapeutic effects even at lower dosages in the respiratory tract (Larios Mora et al. 2018). A phase, I/IIa trial on hospitalised RSV-infected children (aged 1-24 months) revealed a reduction in viral load in nasal swabs after daily treatment with ALX-0171 via inhalation device for three consecutive days (Cunningham et al. 2021). Despite encouraging results in numerous animal models, research has been halted due to a lack of effectiveness data during a phase 2 study in children (in Japan) (Sécher et al. 2019). An intranasal treatment is critical, especially when treating an acute disease in a clinical setting, where the administered dose is a limiting factor and makes it more cost-effective.

Nebulisation is a medication conveyance framework used to deliver medication in the form of a mist inhaled into the lungs and is one of the preferred methods used for uniform and quick delivery of mAbs to the lungs while minimising protein degradation and aggregation (Respaud et al. 2015; Hertel et al. 2015). The other, more favoured way to increase the concentration of mAbs in the inhaled fraction is to couple the mAb with nanoparticles. The use of nanoparticles as delivery systems allows for a reduction in antibody dosing, increases area of coverage, reduces immunogenicity, and controlled release (Sousa et al. 2017). However, the half-life of inhaled Abs in humans is approximately 16-24 h ( 1 day) (Koussoroplis et al. 2014; Matthews et al. 2020). The encapsulation of antibodies in nanoparticles allows for the slow release of these antibodies, resulting in an increase in their overall bioavailability. The post-nebulisation stability profile of mAbs in the respiratory tract is a practical challenge. Gai et al. (2020) have shown that a nanobody developed against the nCOV-19 showed high stability post-nebulisation. To increase antibody retention in respiratory mucosa, Zhang et al. (2020) engineered a human antibody that recognises SARS-CoV-2 S1 spike protein with a higher affinity for mucin and was found to be effective in both nasal and lung areas 7 days after viral exposure in a mouse model (Matthews et al. 2020). Other concerns include the possibility of immunogenicity of antibodies used in the nasal spray due to the anticipated long-term frequent use as prophylaxis. However, the use of engineered antibodies with an increased in vivo half-life will significantly reduce the dosing and the risk of immunogenicity (Harding et al. 2010; Borrok et al. 2017).

The other potential challenge with inhaled delivery of $\mathrm{mAbs}$ is the optimal biodistribution of therapeutic antibodies. Antibody allocation fundamentally depends upon the rate of extravasation in the tissues. Generally, extravasation of mAbs in living systems occurs via three different processes, i.e. passive diffusion, convective diffusion, and transcytosis (Ryman and Meibohm 2017). The functioning of these processes depends on the size and physicochemical properties of the biomolecules. Due to the large size of IgG molecules, most of the antibodies from the blood to tissues are distributed through convective transport. Antibodies are large macromolecules that exhibit restricted distribution to the lungs once injected through an intravenous route. After pulmonary delivery, an inhaled antibody enters systemic circulation very slowly via the airways. In the respiratory organs, the inhaled concentration of $\mathrm{mAb}$ is predicted to be higher than that of the blood compartment. Consequently, the concentration profile within the blood compartment might not mirror the actual kinetics of inhaled mAb within the lungs (Guillon et al. 2019). The movement of inhalation and the speed at which aerosol particles are released from the system and pass through the airways also have a strong effect on the patterns of pulmonary deposition. In general, in terms of overall lung deposition and distal airway penetration, a design technique for the inhalation system that pairs slow-moving aerosol with smaller drug particles has so far been seen as the most efficient process (Thompson 1998; Zierenberg 1999; Borghardt et al. 2018).

The lungs are naturally absorptive to several therapeutic peptides and proteins as compared to any other portal of entry into the body. The large absorption surface of the lung is covered with a thin layer of fluid that makes it attractive for the dispersion of inhaled aerosol therapeutics in high concentrations. There are several pharmacokinetic (PK) processes unique to the pulmonary system and the inhalation pathway due to the complexity of the lung, making pulmonary PK typically distinct and much more complicated than that delivered by other pathways (Weber and Hochhaus 2013). The production of inhaled medications and the production of inhalation products should therefore be based on a clear understanding of the entirety of all processes of 
pulmonary PK (Borghardt et al. 2018). Moreover, the presence of antiproteases in the lung surface fluids prevents proteolytic degradation of therapeutic proteins and, in turn, increases their bioavailability. The reduced mucociliary movements in the lungs further promote absorption as compared to the nasal passages and gastrointestinal tract, where the lateral movement of the bulk fluid reduces the residence time of molecules at the absorptive surface (Patton 1996; Patton et al. 2004). It is critical that therapeutic proteins have a longer residence period within the nasal canal in order to maintain the appropriate concentration and delivered volume following nasal delivery so that the therapeutic dosage can be absorbed (Arora et al. 2002). Different formulation methods including keeping the $\mathrm{pH}$ of the nasal formulation within the range of $\mathrm{pH} 4.5$ to 6.5 , are frequently used to produce therapeutic protein deposition inside the nasal mucosa (Pavis et al. 2002). To increase the residence time in the nasal cavity, different dosage forms, such as gelatin, ointments, liposomes, microspheres, and emulsions, have been used.

The other major challenge associated with inhaled therapeutics is the lack of suitable animal models for preclinical studies because of the disparities between human and animal model anatomy, physiology, and respiratory patterns, making it difficult to draw a clear correlation between them. The surface area of the olfactory mucosa differs among species. Rats and mice have long been employed as test animals. In rats, the olfactory region accounts for more than half of the nasal cavity's total surface area, but in humans, the olfactory region accounts for about $3 \%$ to $5 \%$ of the total nasal cavity surface area. When comparing data from animal trials to human data, it is critical to take into account anatomical and histological distinctions Dahl and Mygind, 1998; Lochhead and Thorne 2012; Gizurarson 2012). Macaques are the most appropriate model due to their close similarity to human infants displaying similar ventilation parameters, nose breathers like infants and body weight in the range of a full-term newborn human (Guillon et al. 2019). In recent experiments, researchers has utilised lambs as animal models to studying the pathogenesis, immunological response, and pharmaceutical testing and quantifying the total dosage emitted by the nebuliser per administration by weighing the nebuliser before and after administration and calculating the nebulised volume (Ackermann 2014; Larios Mora et al. 2018). The preterm and neonatal lamb lung has developmental, anatomical, cellular, physiologic, and immunologic characteristics similar to human babies. Furthermore, the lamb lung is vulnerable to respiratory viruses such as RSV strains that infect babies and induce comparable bronchiolar abnormalities (Sitthicharoenchai et al. 2020). A schematic representation of the respiratory system of human, mice, and lamb is shown in Fig. 4.

Antibody-dependent enhancement (ADE) of viral entry is a major concern in many viruses that aggravate the symptoms in secondary infections (Kumar et al. 2020). ADE has also been observed for coronaviruses (Wan et al. 2020). Several studies have shown that the serum antibodies induced by the SARS-CoV spike enhance viral entry into Fc receptor-expressing cells (Kam et al. 2007; Jaume et al. 2011; Wang et al. 2014). A study showed that cats immunised with a recombinant vaccinia virus expressing the spike (S) protein antigen of the coronavirus causing feline infectious peritonitis leads to more severity in future infections as compared to the control group that was challenged with the coronavirus (Corapi et al. 1992). The postulated mechanism behind this was found to be the induction of infection-enhancing antibodies causing ADE (Corapi et al. 1992; Hohdatsu et al. 1998). A study conducted on nAbs

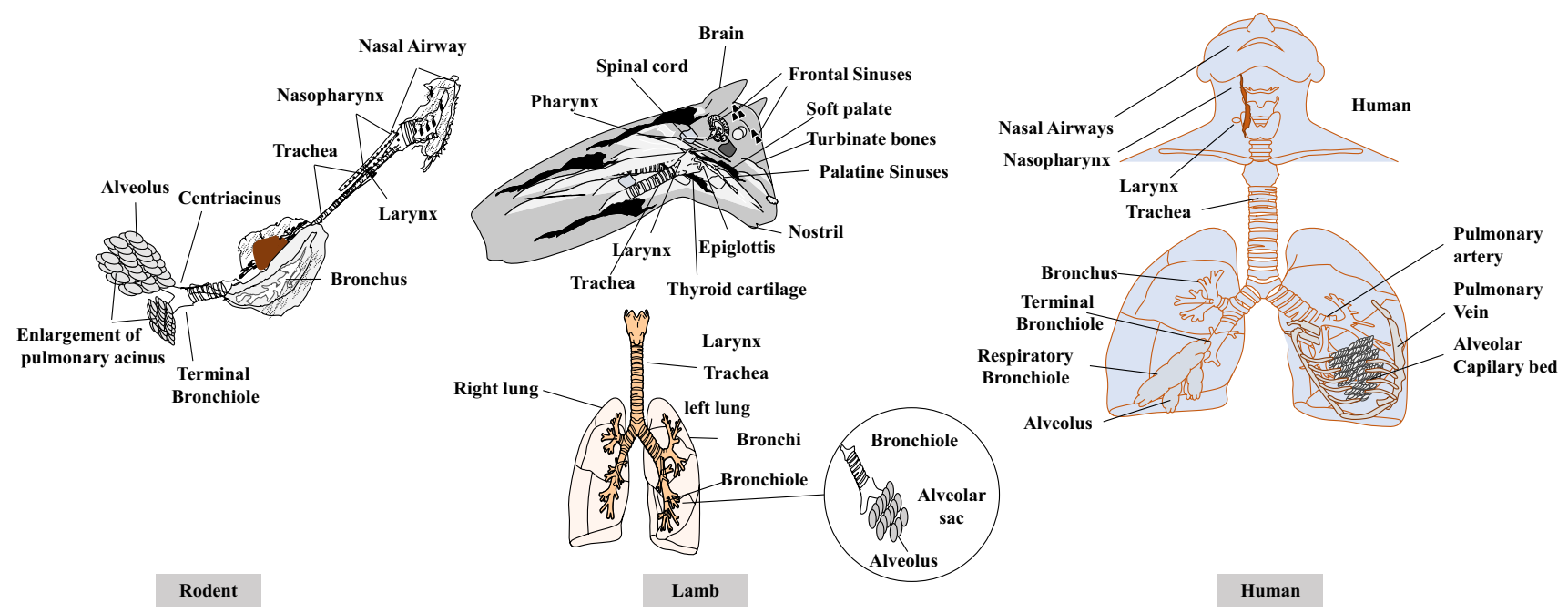

Fig. 4 Schematic view of the respiratory system of mice, lamb, and humans with their parts 
targeting receptor-binding domain (RBD) of MERS-CoV, also supports this and clearly shows the binding of neutralising $\mathrm{Ab}$ triggers the spike to undergo conformational changes that mediate viral entry into $\mathrm{Fc}$ receptor-expressing cells, enhancing infection via ADE (Wan et al. 2020).

Moreover, the current practical challenge that must be explored is the suitability of the isotype of antibody that should be used for intranasal administration, whether it should be IgA or IgG. In the natural mucosal respiratory system, $\operatorname{IgA}$ antibodies are more abundant and provide better protection against respiratory infections, but practically, the production and purification of $\operatorname{IgA}$ antibodies is a big challenge (Weltzin et al. 1996). Unlike IgG antibodies, which are easily purified using protein $\mathrm{A}$ and $\mathrm{G}$ resins due to their affinity for the $\mathrm{Fc}$ region, $\operatorname{IgA}$ antibodies are not easily purified, and there is currently no suitable method for $\operatorname{IgA}$ purification. However, the effectiveness of antibodies in preventing respiratory infection seems to rely mostly on their abundance and localisation, with only a minor influence on the isotype. Mucosal antibodies, $\operatorname{IgA}$ or IgG, are closer to the site of infection than serum antibodies, and this may, therefore, better reflect the protective capacity against respiratory infections (Jacobino et al. 2018).

Additionally, the efficacy of inhaled antibody treatment depends on several factors, like the antibody format used ( $\mathrm{scFv}$, sdAbs, Fab, IgG, IgM, IgA, or IgY), a characteristic that may limit transport through biological membranes (nasal mucosa) (Samson et al. 2012; Parray et al. 2020a). Secondly, the optimal concentration and dosing of the antibody to be used should be assessed, as absorption of the antibody varies from patient to patient (Dupuis-Girod et al. 2014, 2016).

The other practical challenges with the formulation of antibodies as an inhaled delivery system are the requirement of immunoglobulins with favourable biophysical and biochemical properties that can withstand the high forces associated with formulation, delivery, and inhalation. In addition, the choice of the formulation solvent is a critical factor. The molecular, pharmacological, and functional integrity of the antibodies must be maintained during the formulation and delivery process to achieve effective and safe treatment (Respaud et al. 2015). The stability and functionality of the antibodies in various aerosolisation formulations, like polyols, surfactants, sugars, and small amino acids, has been found to have minimal impact on molecular integrity and pharmacological activity. However, the concentration of these stabilisers should be kept to the minimum possible limit to reduce side effects (Montharu et al. 2010; Respaud et al. 2015). Recent studies conducted using llama antibodies with a delivery formulation showed that naturally occurring single domain antibodies are highly soluble, stable, and showing biophysical characteristics well suited for respiratory delivery (Van Heeke et al. 2017).
Epidemiological studies revealed that pathogenicity of severe COVID-19 cases is higher in older age groups as compared to children and their plausible correlation with pre-existing anti-coronaviruses antibodies might have some role in COVID-19 pathogenesis. Moreover, these studies have shown by the presence of pre-existing antibodies that the community would have acquired from viruses which are closely related and have already been endemic in the community. A seroepidemiology and seroprevalence study conducted on human coronavirus HKU1 (HCoV-HKU1) infection in Hong Kong supports the hypothesis that the community contains pre-existing immunity to related coronaviruses (Chan et al. 2009). However, the pre-existing antibodies to other seasonal coronaviruses have been shown to have no effect on COVID-19 severity. Meanwhile, ADE concern cannot be completely neglected for coronavirus infections, especially with the possibility of the co-infection/reinfection with other related viruses or the emergence of new quasispecies harbouring mutations (Ricke 2021).

\section{Perspectives}

Antibody-based therapies have many advantages over vaccine-induced immunity as they provide accelerated protection, are effective in high-risk populations, and can be made available faster than vaccinations in emergencies and outbreaks. A rapid and strategic development of highly targeted preventive and therapeutic antibody-based strategies has the potential to alter the course of an epidemic. Recent outbreaks of viral pathogens (SARS-COV-2) have provided us with an impetus towards developing alternatives to vaccines.

Passive transfer of antibodies through the intranasal or mucosal route for the prevention and treatment of SARS$\mathrm{CoV}-2$ and as a prophylactic is a promising alternative approach for a large population, particularly for developing countries. It provides a promising strategy to prevent SARSCoV-2 infection and control disease severity, to be used as a stand-alone antiviral prophylaxis tool, complementary to future vaccination programs. This approach is suitable to block infection in people who are at high risk of transmitting or causing disease spread in the community, including front-line health-care staff, marginalised populations, the elderly, the immunocompromised, and those with existing comorbidities. In addition, mAbs can be rapidly developed and tested unlike vaccines and may offer a quick solution to overcome community transmission as well as disease progression. In the future, safety issues regarding the human use of mucosal mAbs are likely to be addressed by clinical trials and will open a new way forward towards health management of airborne respiratory infections.

In summary, inhaled therapeutics are most effective when they are designed and administered in their intended location 
in the airways, in tandem with a well-designed inhalation unit that will confer optimal therapeutic concentrations in the respiratory system. The development of cross-reactive and cross-protective antibodies in inhaled formulations effective against diverse coronaviruses (MERS, SARS, CoV2) would extend their use and aid as a pandemic preparedness tool and minimise the economic burden.

Author contribution RK wrote the paper with inputs from KL and SS. RK finalised it with the help of HAP, RP, VS, PK, and SSh. HAP designed the figures. TS, SW, SA, SSa, RKh, RP, VS, PK, CS, and KL edited the manuscript and provided critical inputs in finalising the manuscript.

Funding This work was supported by the Translational Health Science and Technology Institute core grant (T001).

\section{Declarations}

Ethics statement This article does not contain any studies with animals and human samples performed by any of the authors.

Conflict of interest The authors declare no conflict of interest.

\section{References}

Abbas AT, El-Kafrawy SA, Sohrab SS, Azhar EIA (2019) IgY antibodies for the immunoprophylaxis and therapy of respiratory infections. Hum Vaccin Immunother 15:264-275. https://doi.org/10. $1080 / 21645515.2018 .1514224$

Ackermann MR (2014) Lamb model of respiratory syncytial virusassociated lung disease: insights to pathogenesis and novel treatments. ILAR J 55:4-15. https://doi.org/10.1093/ilar/ilu003

Arora P, Sharma S, Garg S (2002) Permeability issues in nasal drug delivery. Drug Discov Today 7:967-975. https://doi.org/10.1016/ s1359-6446(02)02452-2

Bequignon E, Dhommée C, Angely C, Thomas L, Bottier M, Escudier E, Isabey D, Coste A, Louis B, Papon J-F, Gouilleux-Gruart V (2019) FcRn-dependent transcytosis of monoclonal antibody in human nasal epithelial cells in vitro: a prerequisite for a new delivery route for therapy? Int J Mol Sci 20https://doi.org/10. 3390/ijms20061379

Biswas M, Yamazaki T, Chiba J, Akashi-Takamura S (2020) Broadly neutralizing antibodies for influenza: passive immunotherapy and intranasal vaccination. Vaccines (Basel) 8https://doi.org/10.3390/ vaccines 8030424

Bodier-Montagutelli E, Respaud R, Watier H, Guillon-Munos A (2017) MAbDelivery: administration routes for antibody therapy Third LabEx MAbImprove industrial workshop, July 2, 2015 Tours, France. Mabs 9:579-585. https://doi.org/10.1080/19420862. 2017.1298899

Borghardt JM, Kloft C, Sharma A (2018) Inhaled therapy in respiratory disease: the complex interplay of pulmonary kinetic processes. Can Respir J 2018:2732017. https://doi.org/10.1155/2018/27320 17

Borrok MJ, Mody N, Lu X, Kuhn ML, Wu H, Dall'Acqua WF, Tsui P, (2017) An "Fc-Silenced" IgG1 format with extended half-life designed for improved stability. J Pharm Sci 106:1008-1017. https://doi.org/10.1016/j.xphs.2016.12.023
Burgess G, Boyce M, Jones M, Larsson L, Main MJ, Morgan F, Phillips P, Scrimgeour A, Strimenopoulou F, Vajjah P, Zamacona M, Palframan R (2018) Randomized study of the safety and pharmacodynamics of inhaled interleukin-13 monoclonal antibody fragment VR942. EBioMedicine 35:67-75. https://doi.org/10. 1016/j.ebiom.2018.07.035

Calcedo R, Vandenberghe LH, Gao G, Lin J, Wilson JM (2009) Worldwide epidemiology of neutralizing antibodies to adenoassociated viruses. J Infect Dis 199:381-390. https://doi.org/10. $1086 / 595830$

Chan CM, Tse H, Wong SSY, Woo PCY, Lau SKP, Chen L, Zheng BJ, Huang JD, Yuen KY (2009) Examination of seroprevalence of coronavirus HKU1 infection with S protein-based ELISA and neutralization assay against viral spike pseudotyped virus. J Clin Virol 45:54-60. https://doi.org/10.1016/j.jcv.2009.02.011

Chen X, Liao B, Cheng L, Peng X, Xu X, Li Y, Hu T, Li J, Zhou X, Ren B (2020) The microbial coinfection in COVID-19. Appl Microbiol Biotechnol 104:7777-7785. https://doi.org/10.1007/ s00253-020-10814-6

Chirmule N, Propert K, Magosin S, Qian Y, Qian R, Wilson J (1999) Immune responses to adenovirus and adeno-associated virus in humans. Gene Ther 6:1574-1583. https://doi.org/10.1038/sj.gt. 3300994

Cleland JL, Jones AJ (1996) Stable formulations of recombinant human growth hormone and interferon-gamma for microencapsulation in biodegradable microspheres. Pharm Res 13:1464-1475. https://doi.org/10.1023/a:1016063109373

Cohen J (2018) Llama antibodies inspire gene spray to prevent all flus. Science 362:511. https://doi.org/10.1126/science.362.6414.511

Corapi WV, Olsen CW, Scott FW (1992) Monoclonal antibody analysis of neutralization and antibody-dependent enhancement of feline infectious peritonitis virus. J Virol 66:6695-6705. https://doi.org/ 10.1128/JVI.66.11.6695-6705.1992

Cruz-Teran C, Tiruthani K, McSweeney M, Ma A, Pickles R, Lai SK (2021) Challenges and opportunities for antiviral monoclonal antibodies as COVID-19 therapy. Adv Drug Deliv Rev 169:100117. https://doi.org/10.1016/j.addr.2020.12.004

Cunningham S, Piedra PA, Martinon-Torres F, Szymanski H, Brackeva B, Dombrecht E, Detalle L, Fleurinck C, RESPIRE study group, (2021) Nebulised ALX-0171 for respiratory syncytial virus lower respiratory tract infection in hospitalised children: a double-blind, randomised, placebo-controlled, phase $2 \mathrm{~b}$ trial. Lancet Respir Med 9:21-32. https://doi.org/10.1016/S22132600(20)30320-9

Dahl R, Mygind N (1998) Anatomy, physiology and function of the nasal cavities in health and disease. Adv Drug Deliv Rev 29:312. https://doi.org/10.1016/s0169-409x(97)00058-6

Desoubeaux G, Reichert JM, Sleeman M, Reckamp KL, Ryffel B, Adamczewski JP, Sweeney TD, Vanbever R, Diot P, Owen CA, Page C, Lerondel S, Le Pape A, Heuze-Vourc'h N (2016) Therapeutic monoclonal antibodies for respiratory diseases: Current challenges and perspectives, March 31 - April 1, 2016, Tours, France. Mabs 8:999-1009. https://doi.org/10.1080/19420862. 2016.1196521

Detalle L, Stohr T, Palomo C, Piedra PA, Gilbert BE, Mas V, Millar A, Power UF, Stortelers C, Allosery K, Melero JA, Depla E (2016) Generation and characterization of ALX-0171, a potent novel therapeutic nanobody for the treatment of respiratory syncytial virus infection. Antimicrob Agents Chemother 60:6-13. https:// doi.org/10.1128/AAC.01802-15

DiLillo DJ, Tan GS, Palese P, Ravetch JV (2014) Broadly neutralizing hemagglutinin stalk-specific antibodies require Fc $\gamma \mathrm{R}$ interactions for protection against influenza virus in vivo. Nat Med 20:143151. https://doi.org/10.1038/nm.3443

Dupuis-Girod S, Ambrun A, Decullier E, Fargeton A-E, Roux A, Bréant $\mathrm{V}$, Colombet B, Rivière $\mathrm{S}$, Cartier $\mathrm{C}$, Lacombe $\mathrm{P}$, Chinet $\mathrm{T}$, 
Blivet S, Blondel J-H, Gilbert-Dussardier B, Dufour X, Michel J, Harle J-R, Dessi P, Faure F (2016) Effect of bevacizumab nasal spray on epistaxis duration in hereditary hemorrhagic telangectasia: a randomized clinical trial. JAMA 316:934-942. https:// doi.org/10.1001/jama.2016.11387

Dupuis-Girod S, Ambrun A, Decullier E, Samson G, Roux A, Fargeton A-E, Rioufol C, Schwiertz V, Disant F, Chapuis F, Donazzolo Y, Paintaud G, Edery P, Faure F (2014) ELLIPSE Study: a Phase 1 study evaluating the tolerance of bevacizumab nasal spray in the treatment of epistaxis in hereditary hemorrhagic telangiectasia. Mabs 6:794-799. https://doi.org/10.4161/mabs.28025

Durham ND, Agrawal A, Waltari E, Croote D, Zanini F, Fouch M, Davidson E, Smith O, Carabajal E, Pak JE, Doranz BJ, Robinson M, Sanz AM, Albornoz LL, Rosso F, Einav S, Quake SR, McCutcheon KM, Goo L (2019) Broadly neutralizing human antibodies against dengue virus identified by single B cell transcriptomics. Elife 8https://doi.org/10.7554/eLife.52384

Eichhoff AM, Börner K, Albrecht B, Schäfer W, Baum N, Haag F, Körbelin J, Trepel M, Braren I, Grimm D, Adriouch S, Koch-Nolte F (2019) Nanobody-enhanced targeting of AAV gene therapy vectors. Mol Ther Methods Clin Dev 15:211-220. https://doi. org/10.1016/j.omtm.2019.09.003

Faghihi H, Najafabadi AR, Vatanara A (2017) Optimization and characterization of spray-dried $\mathrm{IgG}$ formulations: a design of experiment approach. DARU J Pharm Sci 25:22. https://doi.org/10. 1186/s40199-017-0187-8

Fahy JV, Cockcroft DW, Boulet LP, Wong HH, Deschesnes F, Davis EE, Ruppel J, Su JQ, Adelman DC (1999) Effect of aerosolized anti-IgE (E25) on airway responses to inhaled allergen in asthmatic subjects. Am J Respir Crit Care Med 160:1023-1027. https://doi.org/10.1164/ajrccm.160.3.9810012

Fathe K, Ferrati S, Moraga-Espinoza D, Yazdi A, Smyth HDC (2016) Inhaled biologics:from preclinical to product approval. Curr Pharm Des 22:2501-2521. https://doi.org/10.2174/1381612822 666160210142910

Fick RB, Fox JA, Jardieu PM (2000) Immunotherapy approach to allergic disease. Immunopharmacology 48:307-310. https://doi.org/ 10.1016/s0162-3109(00)00229-0

Flyak AI, Kuzmina N, Murin CD, Bryan C, Davidson E, Gilchuk P, Gulka CP, Ilinykh PA, Shen X, Huang K, Ramanathan P, Turner H, Fusco ML, Lampley R, Kose N, King H, Sapparapu G, Doranz BJ, Ksiazek TG, Wright DW, Saphire EO, Ward AB, Bukreyev A, Crowe JE (2018) Broadly neutralizing antibodies from human survivors target a conserved site in the Ebola virus glycoprotein HR2-MPER region. Nat Microbiol 3:670-677. https://doi.org/10.1038/s41564-018-0157-z

Fontanet A, Autran B, Lina B, Kieny MP, Karim SSA, Sridhar D (2021) SARS-CoV-2 variants and ending the COVID-19 pandemic. Lancet 397:952-954. https://doi.org/10.1016/S01406736(21)00370-6

Forthal DN (2014) Functions of Antibodies. Microbiol Spectr 2:1-17

Fu C-Y, Huang H, Wang X-M, Liu Y-G, Wang Z-G, Cui S-J, Gao H-L, Li Z, Li J-P, Kong X-G (2006) Preparation and evaluation of antiSARS coronavirus IgY from yolks of immunized SPF chickens. J Virol Methods 133:112-115. https://doi.org/10.1016/j.jviromet. 2005.10.027

Gai J, Ma L, Li G, Zhu M, Qiao P, Li X, Zhang H, Zhang Y, Chen Y, Gong R, Wan Y (2020) A potent neutralizing nanobody against SARS-CoV-2 with inhaled delivery potential. bioRxiv 2020.08.09.242867. https://doi.org/10.1101/2020.08.09.242867

Garantziotis S, Schwartz DA (2010) Ecogenomics of respiratory diseases of public health significance. Annu Rev Public Health 31:37-51. https://doi.org/10.1146/annurev.publhealth.012809. 103633

Gerna G, Percivalle E, Perez L, Lanzavecchia A, Lilleri D (2016) Monoclonal antibodies to different components of the human cytomegalovirus (HCMV) pentamer $\mathrm{gH} / \mathrm{gL} / \mathrm{pUL} 128 \mathrm{~L}$ and trimer $\mathrm{gH} / \mathrm{gL} / \mathrm{gO}$ as well as antibodies elicited during primary HCMV infection prevent epithelial cell syncytium formation. J Virol 90:6216-6223. https://doi.org/10.1128/JVI.00121-16

Gizurarson S (2012) Anatomical and histological factors affecting intranasal drug and vaccine delivery. Curr Drug Deliv 9:566582. https://doi.org/10.2174/156720112803529828

Gomi R, Sharma A, Wu W, Worgall S (2018) Neonatal genetic delivery of anti-respiratory syncytial virus (RSV) antibody by non-human primate-based adenoviral vector to provide protection against RSV. Vaccines (Basel) 7https://doi.org/10.3390/vaccines7010003

Grandin C, Hourani M-L, Janin YL, Dauzonne D, Munier-Lehmann H, Paturet A, Taborik F, Vabret A, Contamin H, Tangy F, Vidalain $\mathrm{P}-\mathrm{O}$ (2016) Respiratory syncytial virus infection in macaques is not suppressed by intranasal sprays of pyrimidine biosynthesis inhibitors. Antiviral Res 125:58-62. https://doi.org/10.1016/j. antiviral.2015.11.006

Grandin C, Lucas-Hourani M, Clavel M, Taborik F, Vabret A, Tangy F, Contamin H, Vidalain P-O (2015) Evidence for an intranasal immune response to human respiratory syncytial virus infection in cynomolgus macaques. J Gen Virol 96:782-792. https://doi. org/10.1099/vir.0.000039

Guilleminault L, Azzopardi N, Arnoult C, Sobilo J, Hervé V, Montharu J, Guillon A, Andres C, Herault O, Le Pape A, Diot P, Lemarié E, Paintaud G, Gouilleux-Gruart V, Heuzé-Vourc'h N, (2014) Fate of inhaled monoclonal antibodies after the deposition of aerosolized particles in the respiratory system. J Control Release 196:344-354. https://doi.org/10.1016/j.jconrel.2014.10.003

Guillon A, Pardessus J, Lhommet P, Parent C, Respaud R, Marchand D, Montharu J, De Monte M, Janiak P, Boixel C, Audat H, Huille S, Guillot E, Heuze-Vourc'h N, (2019) Exploring the fate of inhaled monoclonal antibody in the lung parenchyma by microdialysis. Mabs 11:297-304. https://doi.org/10.1080/19420 862.2018.1556081

Hacha J, Tomlinson K, Maertens L, Paulissen G, Rocks N, Foidart J-M, Noel A, Palframan R, Gueders M, Cataldo DD (2012) Nebulized anti-IL-13 monoclonal antibody Fab' fragment reduces allergeninduced asthma. Am J Respir Cell Mol Biol 47:709-717. https:// doi.org/10.1165/rcmb.2012-0031OC

Halbert CL, Miller AD, McNamara S, Emerson J, Gibson RL, Ramsey B, Aitken ML (2006) Prevalence of neutralizing antibodies against adeno-associated virus (AAV) types 2, 5, and 6 in cystic fibrosis and normal populations: implications for gene therapy using AAV vectors. Hum Gene Ther 17:440-447. https://doi.org/ 10.1089/hum.2006.17.440

Hansel TT, Kropshofer H, Singer T, Mitchell JA, George AJT (2010) The safety and side effects of monoclonal antibodies. Nat Rev Drug Discov 9:325-338. https://doi.org/10.1038/nrd3003

Harding FA, Stickler MM, Razo J, DuBridge RB (2010) The immunogenicity of humanized and fully human antibodies: residual immunogenicity resides in the CDR regions. Mabs 2:256-265. https://doi.org/10.4161/mabs.2.3.11641

Harmsen MM, De Haard HJ (2007) Properties, production, and applications of camelid single-domain antibody fragments. Appl Microbiol Biotechnol 77:13-22. https://doi.org/10.1007/ s00253-007-1142-2

Hart TK, Cook RM, Zia-Amirhosseini P, Minthorn E, Sellers TS, Maleeff BE, Eustis S, Schwartz LW, Tsui P, Appelbaum ER, Martin EC, Bugelski PJ, Herzyk DJ (2001) Preclinical efficacy and safety of mepolizumab (SB-240563), a humanized monoclonal antibody to IL-5, in cynomolgus monkeys. J Allergy Clin Immunol 108:250-257. https://doi.org/10.1067/mai.2001.116576

Hemming VG, Prince GA, Horswood RL, London WJ, Murphy BR, Walsh EE, Fischer GW, Weisman LE, Baron PA, Chanock RM (1985) Studies of passive immunotherapy for infections of respiratory syncytial virus in the respiratory tract of a primate model. $\mathrm{J}$ 
Infect Dis 152:1083-1087. https://doi.org/10.1093/infdis/152.5. 1083

Hemming VG, Prince GA, London WT, Baron PA, Brown R, Chanock RM (1988) Topically administered immunoglobulin reduces pulmonary respiratory syncytial virus shedding in owl monkeys. Antimicrob Agents Chemother 32:1269-1270. https://doi.org/ 10.1128/aac.32.8.1269

Hertel SP, Winter G, Friess W (2015) Protein stability in pulmonary drug delivery via nebulization. Adv Drug Deliv Rev 93:79-94. https://doi.org/10.1016/j.addr.2014.10.003

Hervé V, Rabbe N, Guilleminault L, Paul F, Schlick L, Azzopardi N, Duruisseaux M, Fouquenet D, Montharu J, Redini F, Paintaud G, Lemarié E, Cadranel J, Wislez M, Heuzé-Vourc'h N (2014) VEGF neutralizing aerosol therapy in primary pulmonary adenocarcinoma with K-ras activating-mutations. Mabs 6:1638-1648. https://doi.org/10.4161/mabs.34454

Hohdatsu T, Yamada M, Tominaga R, Makino K, Kida K, Koyama $\mathrm{H}$ (1998) Antibody-dependent enhancement of feline infectious peritonitis virus infection in feline alveolar macrophages and human monocyte cell line U937 by serum of cats experimentally or naturally infected with feline coronavirus. J Vet Med Sci 60:49-55. https://doi.org/10.1292/jvms.60.49

Hollevoet K, Declerck PJ (2017) State of play and clinical prospects of antibody gene transfer. J Transl Med 15https://doi.org/10.1186/ s12967-017-1234-4

Hong B, Wen Y, Ying T (2019) Recent progress on neutralizing antibodies against hepatitis B virus and its implications. Infect Disord Drug Targets 19:213-223. https://doi.org/10.2174/18715 26518666180628122400

Ibañez LI, De Filette M, Hultberg A, Verrips T, Temperton N, Weiss RA, Vandevelde W, Schepens B, Vanlandschoot P, Saelens $X$ (2011) Nanobodies with in vitro neutralizing activity protect mice against $\mathrm{H} 5 \mathrm{~N} 1$ influenza virus infection. J Infect Dis 203:1063-1072. https://doi.org/10.1093/infdis/jiq168

Ibrahim M, Verma R, Garcia-Contreras L (2015) Inhalation drug delivery devices: technology update. Med Devices (auckl) 8:131-139. https://doi.org/10.2147/MDER.S48888

Ilan Y, Shailubhai K, Sanyal A (2018) Immunotherapy with oral administration of humanized anti-CD3 monoclonal antibody: a novel gut-immune system-based therapy for metaflammation and NASH. Clin Exp Immunol 193:275-283. https://doi.org/10. 1111/cei.13159

Jacobino SR, Nederend M, Reijneveld JF, Augustijn D, Jansen JHM, Meeldijk J, Reiding KR, Wuhrer M, Coenjaerts FEJ, Hack CE, Bont LJ, Leusen JHW (2018) Reformatting palivizumab and motavizumab from IgG to human IgA impairs their efficacy against RSV infection in vitro and in vivo. Mabs 10:453-462. https://doi.org/10.1080/19420862.2018.1433974

Jaume M, Yip MS, Cheung CY, Leung HL, Li PH, Kien F, Dutry I, Callendret B, Escriou N, Altmeyer R, Nal B, Daëron M, Bruzzone R, Peiris JSM (2011) Anti-severe acute respiratory syndrome coronavirus spike antibodies trigger infection of human immune cells via a $\mathrm{pH}$ - and cysteine protease-independent $\mathrm{Fc} \gamma \mathrm{R}$ pathway. J Virol 85:10582-10597. https://doi.org/10.1128/JVI. 00671-11

Jayasundera M, Adhikari B, Adhikari R, Aldred P (2011) The effects of proteins and low molecular weight surfactants on spray drying of model sugar-rich foods: powder production and characterisation. J Food Eng 104:259-271. https://doi.org/10.1016/j.jfood eng.2010.12.017

Jones RGA, Martino A (2016) Targeted localized use of therapeutic antibodies: a review of non-systemic, topical and oral applications. Crit Rev Biotechnol 36:506-520. https://doi.org/10.3109/ 07388551.2014 .992388

Kam YW, Kien F, Roberts A, Cheung YC, Lamirande EW, Vogel L, Chu SL, Tse J, Guarner J, Zaki SR, Subbarao K, Peiris M,
Nal B, Altmeyer R (2007) Antibodies against trimeric S glycoprotein protect hamsters against SARS-CoV challenge despite their capacity to mediate FcgammaRII-dependent entry into B cells in vitro. Vaccine 25:729-740. https://doi.org/10.1016/j. vaccine.2006.08.011

Kane C, O’Neil K, Conk M, Picha K (2013) Inhalation delivery of protein therapeutics. Inflamm Allergy Drug Targets 12:81-87. https://doi.org/10.2174/1871528111312020002

Kang MC, Choi D-H, Choi YW, Park SJ, Namkoong H, Park KS, Ahn S-S, Surh CD, Yoon S-W, Kim D-J, Choi J, Park Y, Sung YC, Lee S-W (2015) Intranasal introduction of Fc-fused interleukin-7 provides long-lasting prophylaxis against lethal influenza virus infection. J Virol 90:2273-2284. https://doi.org/10. 1128/JVI.02768-15

Karnam A, Rambabu N, Das M, Bou-Jaoudeh M, Delignat S, Käsermann F, Lacroix-Desmazes S, Kaveri SV, Bayry J (2020) Therapeutic normal IgG intravenous immunoglobulin activates Wnt- $\beta$-catenin pathway in dendritic cells. Communications Biology 3:1-13. https://doi.org/10.1038/s42003-020-0825-4

Khan L, Kumar R, Thiruvengadam R, Parray HA, Makhdoomi MA, Kumar S, Aggarwal H, Mohata M, Hussain AW, Das R, Varadarajan R, Bhattacharya J, Vajpayee M, Murugavel KG, Solomon S, Sinha S, Luthra K (2017) Cross-neutralizing anti-HIV-1 human single chain variable fragments(scFvs) against CD4 binding site and N332 glycan identified from a recombinant phage library. Scientific Reports 7https://doi.org/10.1038/srep45163

Kim N, Duncan GA, Hanes J, Suk JS (2016) Barriers to inhaled gene therapy of obstructive lung diseases: a review. J Control Release 240:465-488. https://doi.org/10.1016/j.jconrel.2016.05.031

Kim PK, Keum SJ, Osinubi MOV, Franka R, Shin JY, Park ST, Kim MS, Park MJ, Lee SY, Carson W, Greenberg L, Yu P, Tao X, Lihua W, Tang Q, Liang G, Shampur M, Rupprecht CE, Chang SJ (2017) Development and characterization of novel chimeric monoclonal antibodies for broad spectrum neutralization of rabies virus. PLoS ONE 12:e0186380. https://doi.org/10.1371/ journal.pone. 0186380

Koleba T, Ensom MHH (2006) Pharmacokinetics of intravenous immunoglobulin: a systematic review. Pharmacotherapy 26:813-827. https://doi.org/10.1592/phco.26.6.813

Koussoroplis SJ, Paulissen G, Tyteca D, Goldansaz H, Todoroff J, Barilly C, Uyttenhove C, Van Snick J, Cataldo D, Vanbever R (2014) PEGylation of antibody fragments greatly increases their local residence time following delivery to the respiratory tract. J Control Release 187:91-100. https://doi.org/10.1016/j.jconrel. 2014.05.021

Kovacs-Nolan J, Mine Y (2012) Egg yolk antibodies for passive immunity. Annu Rev Food Sci Technol 3:163-182. https://doi.org/10. 1146/annurev-food-022811-101137

Kumar R, Andrabi R, Tiwari A, Prakash SS, Wig N, Dutta D, Sankhyan A, Khan L, Sinha S, Luthra K (2012) A novel strategy for efficient production of anti-V3 human scFvs against HIV-1 clade C. BMC Biotechnol 12:87. https://doi.org/10.1186/ 1472-6750-12-87

Kumar R, Kumari R, Khan L, Sankhyan A, Parray HA, Tiwari A, Wig N, Sinha S, Luthra K (2019a) Isolation and characterization of cross-neutralizing human anti-V3 single-chain variable fragments (scFvs) against HIV-1 from an antigen preselected phage library. Appl Biochem Biotechnol 187:1011-1027. https://doi. org/10.1007/s12010-018-2862-8

Kumar R, Parray HA, Shrivastava T, Sinha S, Luthra K (2019b) Phage display antibody libraries: a robust approach for generation of recombinant human monoclonal antibodies. Int J Biol Macromol 135:907-918. https://doi.org/10.1016/j.ijbiomac.2019.06.006

Kumar R, Qureshi H, Deshpande S, Bhattacharya J (2018) Broadly neutralizing antibodies in HIV-1 treatment and prevention. Ther 
Adv Vaccines Immunother 6:61-68. https://doi.org/10.1177/ 2515135518800689

Kumar R, Shrivastava T, Samal S, Ahmed S, Parray HA (2020) Antibody-based therapeutic interventions: possible strategy to counter chikungunya viral infection. Appl Microbiol Biotechnol 104:3209-3228. https://doi.org/10.1007/s00253-020-10437-x

Labiris NR, Dolovich MB (2003) Pulmonary drug delivery. Part I: physiological factors affecting therapeutic effectiveness of aerosolized medications. Br J Clin Pharmacol 56:588-599. https:// doi.org/10.1046/j.1365-2125.2003.01892.x

Larios Mora A, Detalle L, Gallup JM, Van Geelen A, Stohr T, Duprez L, Ackermann MR (2018) Delivery of ALX-0171 by inhalation greatly reduces respiratory syncytial virus disease in newborn lambs. Mabs 10:778-795. https://doi.org/10.1080/19420862. 2018.1470727

Lemamy GJ, Roger P, Mani JC, Robert M, Rochefort H, Brouillet JP (1999) High-affinity antibodies from hen's-egg yolks against human mannose-6-phosphate/insulin-like growth-factor-II receptor (M6P/IGFII-R): characterization and potential use in clinical cancer studies. Int J Cancer 80:896-902. https://doi.org/10.1002/ (sici)1097-0215(19990315)80:6\%3c896::aid-ijc16\%3e3.0.co;2-j

Leyva-Grado VH, Tan GS, Leon PE, Yondola M, Palese P (2015) Direct administration in the respiratory tract improves efficacy of broadly neutralizing anti-influenza virus monoclonal antibodies. Antimicrob Agents Chemother 59:4162-4172. https://doi. org/10.1128/AAC.00290-15

Li M, Kroetz DL (2018) Bevacizumab-induced hypertension: clinical presentation and molecular understanding. Pharmacol Ther 182:152-160. https://doi.org/10.1016/j.pharmthera.2017.08.012

Li X, Wang L, Zhen Y, Li S, Xu Y (2015) Chicken egg yolk antibodies (IgY) as non-antibiotic production enhancers for use in swine production: a review. J Anim Sci Biotechnol 6https://doi.org/10. 1186/s40104-015-0038-8

Li Y, Jin L, Chen T (2020) The effects of secretory IgA in the mucosal immune system. Biomed Res Int 2020:2032057. https://doi.org/ $10.1155 / 2020 / 2032057$

Liang W, Pan HW, Vllasaliu D, Lam JKW (2020) Pulmonary delivery of biological drugs. Pharmaceutics 12https://doi.org/10.3390/ pharmaceutics 12111025

Liao Y-H, Brown MB, Jones SA, Nazir T, Martin GP (2005) The effects of polyvinyl alcohol on the in vitro stability and delivery of spray-dried protein particles from surfactant-free HFA 134a-based pressurised metered dose inhalers. Int J Pharm 304:29-39. https://doi.org/10.1016/j.ijpharm.2005.07.013

Lochhead JJ, Thorne RG (2012) Intranasal delivery of biologics to the central nervous system. Adv Drug Deliv Rev 64:614-628. https://doi.org/10.1016/j.addr.2011.11.002

Maillet A, Guilleminault L, Lemarié E, Lerondel S, Azzopardi N, Montharu J, Congy-Jolivet N, Reverdiau P, Legrain B, Parent C, Douvin D-H, Hureaux J, Courty Y, De Monte M, Diot P, Paintaud G, Le Pape A, Watier H, Heuzé-Vourc'h N (2011) The airways, a novel route for delivering monoclonal antibodies to treat lung tumors. Pharm Res 28:2147-2156. https://doi.org/10. 1007/s11095-011-0442-5

Manjarrez-Zavala ME, Rosete-Olvera DP, Gutiérrez-González LH, Ocadiz-Delgado R, Cabello-Gutiérrez C (2013) Pathogenesis of viral respiratory infection. Respiratory disease and infection - a new insight. https://doi.org/10.5772/54287

Markham A (2021) REGN-EB3: first approval. Drugs 81:175-178. https://doi.org/10.1007/s40265-020-01452-3

Matthews AA, Ee PLR, Ge R (2020) Developing inhaled protein therapeutics for lung diseases. Mol Biomed 1:11. https://doi.org/10. 1186/s43556-020-00014-z

Mayor A, Thibert B, Huille S, Respaud R, Audat H, Heuzé-Vourc'h $\mathrm{N}$, (2021) Inhaled antibodies: formulations require specific development to overcome instability due to nebulization. Drug Deliv Transl Res. https://doi.org/10.1007/s13346-021-00967-w

Mojtabavi H, Saghazadeh A, Rezaei N (2020) Interleukin-6 and severe COVID-19: a systematic review and metaanalysis. Eur Cytokine Netw 31:44-49. https://doi.org/10.1684/ecn.2020.0448

Montharu J, Le Guellec S, Kittel B, Rabemampianina Y, Guillemain J, Gauthier F, Diot P, de Monte M (2010) Evaluation of lung tolerance of ethanol, propylene glycol, and sorbitan monooleate as solvents in medical aerosols. J Aerosol Med Pulm Drug Deliv 23:41-46. https://doi.org/10.1089/jamp.2008.0740

Moreno M, Pow PY, Tabitha TST, Nirmal S, Larsson A, Radhakrishnan K, Nirmal J, Quah ST, Geifman Shochat S, Agrawal R, Venkatraman S (2017) Modulating release of ranibizumab and aflibercept from thiolated chitosan-based hydrogels for potential treatment of ocular neovascularization. Expert Opin Drug Deliv 14:913925. https://doi.org/10.1080/17425247.2017.1343297

Moroni-Zentgraf P, Usmani OS, Halpin DMG (2018) Inhalation devices. Can Respir J 2018:5642074. https://doi.org/10.1155/ $2018 / 5642074$

Mullard A (2020) COVID-19 vaccine development pipeline gears up. Lancet 395:1751-1752. https://doi.org/10.1016/S0140-6736(20) 31252-6

Mumenthaler M, Hsu CC, Pearlman R (1994) Feasibility study on spray-drying protein pharmaceuticals: recombinant human growth hormone and tissue-type plasminogen activator. Pharm Res 11:12-20. https://doi.org/10.1023/a:1018929224005

Nilsson E, Larsson A, Olesen HV, Wejåker P-E, Kollberg H (2008) Good effect of IgY against Pseudomonas aeruginosa infections in cystic fibrosis patients. Pediatr Pulmonol 43:892-899. https:// doi.org/10.1002/ppul.20875

Ogura M, Deng S, Preston-Hurlburt P, Ogura H, Shailubhai K, Kuhn C, Weiner HL, Herold KC (2017) Oral treatment with foralumab, a fully human anti-CD3 monoclonal antibody, prevents skin xenograft rejection in humanized mice. Clin Immunol 183:240-246. https://doi.org/10.1016/j.clim.2017.07.005

Olchanski N, Hansen RN, Pope E, D'Cruz B, Fergie J, Goldstein M, Krilov LR, McLaurin KK, Nabrit-Stephens B, Oster G, Schaecher K, Shaya FT, Neumann PJ, Sullivan SD (2018) Palivizumab prophylaxis for respiratory syncytial virus: examining the evidence around value. Open Forum Infect Dis 5:ofy031. https:// doi.org/10.1093/ofid/ofy031

Olmsted SS, Padgett JL, Yudin AI, Whaley KJ, Moench TR, Cone RA (2001) Diffusion of macromolecules and virus-like particles in human cervical mucus. Biophys J 81:1930-1937. https://doi.org/ 10.1016/S0006-3495(01)75844-4

Parray HA, Chiranjivi AK, Asthana S, Yadav N, Shrivastava T, Mani S, Sharma C, Vishwakarma P, Das S, Pindari K, Sinha S, Samal S, Ahmed S, Kumar R (2020a) Identification of an anti-SARSCoV-2 receptor binding domain directed human monoclonal antibody from a naïve semi-synthetic library. J Biol Chem. https:// doi.org/10.1074/jbc.AC120.014918

Parray HA, Shukla S, Samal S, Shrivastava T, Ahmed S, Sharma C, Kumar R (2020b) Hybridoma technology a versatile method for isolation of monoclonal antibodies, its applicability across species, limitations, advancement and future perspectives. Int Immunopharmacol 85:106639. https://doi.org/10.1016/j.intimp. 2020.106639

Patel A, Bah MA, Weiner DB (2020) In Vivo Delivery of Nucleic Acid-Encoded Monoclonal Antibodies. BioDrugs 34:273-293. https://doi.org/10.1007/s40259-020-00412-3

Patton JS (1996) Mechanisms of macromolecule absorption by the lungs. Adv Drug Deliv Rev 19:3-36. https://doi.org/10.1016/ 0169-409X(95)00113-L

Patton JS, Fishburn CS, Weers JG (2004) The lungs as a portal of entry for systemic drug delivery. Proc Am Thorac Soc 1:338-344. https://doi.org/10.1513/pats.200409-049TA 
Pavis H, Wilcock A, Edgecombe J, Carr D, Manderson C, Church A, Fisher A (2002) Pilot study of nasal morphine-chitosan for the relief of breakthrough pain in patients with cancer. J Pain Symptom Manage 24:598-602. https://doi.org/10.1016/s08853924(02)00522-5

Pérez de la Lastra JM, Baca-González V, Asensio-Calavia P, GonzálezAcosta S, Morales-delaNuez A (2020) Can Immunization of Hens Provide Oral-Based Therapeutics against COVID-19? Vaccines (Basel) 8https://doi.org/10.3390/vaccines8030486

Perween R, Ahmed S, Shrivastava T, Parray HA, Singh B, Pindari KS, Sharma C, Shukla S, Sinha S, Panchal AK, Kumar R (2021) A rapid novel strategy for screening of antibody phage libraries for production, purification, and functional characterization of amber stop codons containing single-chain antibody fragments. Biotechnol Prog e3136. https://doi.org/10.1002/btpr.3136

Petrosillo N, Viceconte G, Ergonul O, Ippolito G, Petersen E (2020) COVID-19, SARS and MERS: are they closely related? Clin Microbiol Infect 26:729-734. https://doi.org/10.1016/j.cmi.2020. 03.026

Piepenbrink MS, Park J-G, Oladunni FS, Deshpande A, Basu M, Sarkar S, Loos A, Woo J, Lovalenti P, Sloan D, Ye C, Chiem K, Bates CW, Burch RE, Erdmann NB, Goepfert PA, Truong VL, Walter MR, Martinez-Sobrido L, Kobie JJ (2021) Therapeutic activity of an inhaled potent SARS-CoV-2 neutralizing human monoclonal antibody in hamsters. Cell Reports Medicine 2:100218. https:// doi.org/10.1016/j.xcrm.2021.100218

Pinto D, Park Y-J, Beltramello M, Walls AC, Tortorici MA, Bianchi S, Jaconi S, Culap K, Zatta F, De Marco A, Peter A, Guarino B, Spreafico R, Cameroni E, Case JB, Chen RE, Havenar-Daughton C, Snell G, Telenti A, Virgin HW, Lanzavecchia A, Diamond MS, Fink K, Veesler D, Corti D (2020) Cross-neutralization of SARS-CoV-2 by a human monoclonal SARS-CoV antibody. Nature. https://doi.org/10.1038/s41586-020-2349-y

Posner J, Barrington P, Brier T, Datta-Mannan A (2019) Monoclonal antibodies: past, present and future. Handb Exp Pharmacol 260:81-141. https://doi.org/10.1007/164_2019_323

Prabakaran P, Zhongyu Z, Xiao X, Biragyn A, Dimitrov AS, Broder CC, Dimitrov DS (2009) Potent human monoclonal antibodies against SARS CoV, Nipah and Hendra viruses. Expert Opin Biol Ther 9:355-368. https://doi.org/10.1517/14712590902763755

Prince GA, Hemming VG, Horswood RL, Baron PA, Chanock RM (1987) Effectiveness of topically administered neutralizing antibodies in experimental immunotherapy of respiratory syncytial virus infection in cotton rats. J Virol 61:1851-1854

Prince GA, Hemming VG, Horswood RL, Chanock RM (1985) Immunoprophylaxis and immunotherapy of respiratory syncytial virus infection in the cotton rat. Virus Res 3:193-206. https://doi.org/ 10.1016/0168-1702(85)90045-0

Rahman S, Van Nguyen S, Icatlo FC Jr, Umeda K, Kodama Y (2013) Oral passive IgY-based immunotherapeutics. Hum Vaccin Immunother 9:1039-1048. https://doi.org/10.4161/hv.23383

Respaud R, Marchand D, Parent C, Pelat T, Thullier P, Tournamille J-F, Viaud-Massuard M-C, Diot P, Si-Tahar M, Vecellio L, HeuzéVourc'h N (2014) Effect of formulation on the stability and aerosol performance of a nebulized antibody. Mabs 6:1347-1355. https://doi.org/10.4161/mabs.29938

Respaud R, Vecellio L, Diot P, Heuzé-Vourc'h N, (2015) Nebulization as a delivery method for mAbs in respiratory diseases. Expert Opin Drug Deliv 12:1027-1039. https://doi.org/10.1517/17425 247.2015.999039

Ricke DO (2021) Two Different Antibody-Dependent Enhancement (ADE) Risks for SARS-CoV-2 Antibodies. Front Immunol 12https://doi.org/10.3389/fimmu.2021.640093

Rizza SA, Bhatia R, Zeuli J, Temesgen Z (2019) Ibalizumab for the treatment of multidrug-resistant HIV-1 infection. Drugs Today (barc) 55:25-34. https://doi.org/10.1358/dot.2019.55.1.2895651
Ross TM, Martinez PM, Renner JC, Thorne RG, Hanson LR, Frey WH (2004) Intranasal administration of interferon beta bypasses the blood-brain barrier to target the central nervous system and cervical lymph nodes: a non-invasive treatment strategy for multiple sclerosis. J Neuroimmunol 151:66-77. https://doi.org/10.1016/j.jneuroim.2004.02.011

Ryman JT, Meibohm B (2017) Pharmacokinetics of monoclonal antibodies. CPT Pharmacometrics Syst Pharmacol 6:576-588. https://doi.org/10.1002/psp4.12224

Sakagami M, Omidi Y, Campbell L, Kandalaft LE, Morris CJ, Barar J, Gumbleton M (2006) Expression and transport functionality of FcRn within rat alveolar epithelium: a study in primary cell culture and in the isolated perfused lung. Pharm Res 23:270279. https://doi.org/10.1007/s11095-005-9226-0

Saltzman WM, Radomsky ML, Whaley KJ, Cone RA (1994) Antibody diffusion in human cervical mucus. Biophys J 66:508-515. https://doi.org/10.1016/s0006-3495(94)80802-1

Samson G, García de la Calera A, Dupuis-Girod S, Faure F, Decullier E, Paintaud G, Vignault C, Scoazec J-Y, Pivot C, Plauchu H, Pirot F (2012) Ex vivo study of bevacizumab transport through porcine nasal mucosa. Eur J Pharm Biopharm 80:465-469. https://doi.org/10.1016/j.ejpb.2011.11.004

Sapparapu G, Fernandez E, Kose N, Cao Bin, Fox JM, Bombardi RG, Zhao H, Nelson CA, Bryan AL, Barnes T, Davidson E, Mysorekar IU, Fremont DH, Doranz BJ, Diamond MS, Crowe JE (2016) Neutralizing human antibodies prevent Zika virus replication and fetal disease in mice. Nature 540:443-447. https:// doi.org/10.1038/nature20564

Schoof M, Faust B, Saunders RA, Sangwan S, Rezelj V, Hoppe N, Boone M, Billesbølle CB, Puchades C, Azumaya CM, Kratochvil HT, Zimanyi M, Deshpande I, Liang J, Dickinson S, Nguyen HC, Chio CM, Merz GE, Thompson MC, Diwanji D, Schaefer K, Anand AA, Dobzinski N, Zha BS, Simoneau CR, Leon K, White KM, Chio US, Gupta M, Jin M, Li F, Liu Y, Zhang K, Bulkley D, Sun M, Smith AM, Rizo AN, Moss F, Brilot AF, Pourmal S, Trenker R, Pospiech T, Gupta S, Barsi-Rhyne B, Belyy V, BarileHill AW, Nock S, Liu Y, Krogan NJ, Ralston CY, Swaney DL, García-Sastre A, Ott M, Vignuzzi M, Walter P, Manglik A (2020) An ultra-potent synthetic nanobody neutralizes SARS-CoV-2 by locking Spike into an inactive conformation. bioRxiv. https://doi. org/10.1101/2020.08.08.238469

Schweizer D, Serno T, Goepferich A (2014) Controlled release of therapeutic antibody formats. Eur J Pharm Biopharm 88:291-309. https://doi.org/10.1016/j.ejpb.2014.08.001

Sécher T, Mayor A, Heuzé-Vourc'h N (2019) Inhalation of immunotherapeutics/-prophylactics to fight respiratory tract infections: an appropriate drug at the right place! Front Immunol 10. https:// doi.org/10.3389/fimmu.2019.02760

Sitthicharoenchai P, Alnajjar S, Ackermann MR (2020) A model of respiratory syncytial virus (RSV) infection of infants in newborn lambs. Cell Tissue Res 380:313-324. https://doi.org/10.1007/ s00441-020-03213-w

Somasundaram R, Choraria A, Antonysamy M (2020) An approach towards development of monoclonal IgY antibodies against SARS CoV-2 spike protein (S) using phage display method: a review. Int Immunopharmacol 85:106654. https://doi.org/10. 1016/j.intimp.2020.106654

Soto JA, Gálvez NMS, Pacheco GA, Bueno SM, Kalergis AM (2020) Antibody development for preventing the human respiratory syncytial virus pathology. Mol Med 26:35. https://doi.org/10.1186/ s10020-020-00162-6

Sousa F, Castro P, Fonte P, Kennedy PJ, Neves-Petersen MT, Sarmento B (2017) Nanoparticles for the delivery of therapeutic antibodies: dogma or promising strategy? Expert Opin Drug Deliv 14:11631176. https://doi.org/10.1080/17425247.2017.1273345 
Stuart CA, Pietrzyk RA, Furlanetto RW, Green A (1988) High affinity antibody from hen's eggs directed against the human insulin receptor and the human IGF-I receptor. Anal Biochem 173:142150. https://doi.org/10.1016/0003-2697(88)90171-6

Tan GS, Leon PE, Albrecht RA, Margine I, Hirsh A, Bahl J, Krammer F (2016) Broadly-reactive neutralizing and non-neutralizing antibodies directed against the $\mathrm{H} 7$ influenza virus hemagglutinin reveal divergent mechanisms of protection. PLoS Pathog 12:e1005578. https://doi.org/10.1371/journal.ppat.1005578

Tang A, Chen Z, Cox KS, Su H-P, Callahan C, Fridman A, Zhang L, Patel SB, Cejas PJ, Swoyer R, Touch S, Citron MP, Govindarajan D, Luo B, Eddins M, Reid JC, Soisson SM, Galli J, Wang D, Wen Z, Heidecker GJ, Casimiro DR, DiStefano DJ, Vora KA (2019) A potent broadly neutralizing human RSV antibody targets conserved site IV of the fusion glycoprotein. Nat Commun 10:4153. https://doi.org/10.1038/s41467-019-12137-1

Thompson PJ (1998) Drug delivery to the small airways. Am J Respir Crit Care Med 157:S199-202. https://doi.org/10.1164/ajrccm. 157.5.rsaa-7

Van Heeke G, Allosery K, De Brabandere V, De Smedt T, Detalle L, de Fougerolles A (2017) Nanobodies $®$ as inhaled biotherapeutics for lung diseases. Pharmacol Ther 169:47-56. https://doi.org/10. 1016/j.pharmthera.2016.06.012

Viola M, Sequeira J, Seiça R, Veiga F, Serra J, Santos AC, Ribeiro AJ (2018) Subcutaneous delivery of monoclonal antibodies: how do we get there? J Control Release 286:301-314. https://doi.org/10. 1016/j.jconrel.2018.08.001

Vonarburg C, Loetscher M, Spycher MO, Kropf A, Illi M, Salmon S, Roberts S, Steinfuehrer K, Campbell I, Koernig S, Bain J, Edler M, Baumann U, Miescher S, Metzger DW, Schaub A, Käsermann F, Zuercher AW (2019) Topical application of nebulized human $\mathrm{IgG}, \mathrm{IgA}$ and IgAM in the lungs of rats and non-human primates. Respir Res 20:99. https://doi.org/10.1186/s12931-019-1057-3

Wan Y, Shang J, Sun S, Tai W, Chen J, Geng Q, He L, Chen Y, Wu J, Shi Z, Zhou Y, Du L, Li F (2020) Molecular mechanism for antibody-dependent enhancement of coronavirus entry. J Virol 94https://doi.org/10.1128/JVI.02015-19

Wang S-F, Tseng S-P, Yen C-H, Yang J-Y, Tsao C-H, Shen C-W, Chen K-H, Liu F-T, Liu W-T, Chen Y-MA, Huang JC (2014) Antibodydependent SARS coronavirus infection is mediated by antibodies against spike proteins. Biochem Biophys Res Commun 451:208214. https://doi.org/10.1016/j.bbrc.2014.07.090

Weber B, Hochhaus G (2013) A pharmacokinetic simulation tool for inhaled corticosteroids. AAPS J 15:159-171. https://doi.org/10. 1208/s12248-012-9420-z

Weltzin R, Monath TP (1999) Intranasal antibody prophylaxis for protection against viral disease. Clin Microbiol Rev 12:383-393

Weltzin R, Traina-Dorge V, Soike K, Zhang JY, Mack P, Soman G, Drabik G, Monath TP (1996) Intranasal monoclonal IgA antibody to respiratory syncytial virus protects rhesus monkeys against upper and lower respiratory tract infection. J Infect Dis 174:256-261. https://doi.org/10.1093/infdis/174.2.256

Wen J, Zhao S, He D, Yang Y, Li Y, Zhu S (2012) Preparation and characterization of egg yolk immunoglobulin $\mathrm{Y}$ specific to influenza B virus. Antiviral Res 93:154-159. https://doi.org/10.1016/j. antiviral.2011.11.005

Westover JB, Ferrer G, Vazquez H, Bethencourt-Mirabal A, Go CC (2020) In vitro virucidal effect of intranasally delivered chlorpheniramine maleate compound against severe acute respiratory syndrome coronavirus 2. Cureus 12:e10501. https://doi.org/10. 7759/cureus.10501

Wu X, Cheng L, Fu M, Huang B, Zhu L, Xu S, Shi H, Zhang D, Yuan H, Nawaz W, Yang P, Hu Q, Liu Y, Wu Z (2021) A potent bispecific nanobody protects hACE2 mice against SARS-CoV-2 infection via intranasal administration. bioRxiv. https://doi.org/ 10.1101/2021.02.08.429275

Xie M, Meng Y, Li Z, Li Y, Zhang K, Zhao X, Xiong G, Chen Y (2004) Effect of specific immunoglobulin $Y$ in the treatment of acute and chronic pharyngitis. Zhonghua Er Bi Yan Hou Ke Za Zhi 39:112-115

Yang B, Schaefer A, Wang Y-Y, McCallen J, Lee P, Newby JM, Arora H, Kumar PA, Zeitlin L, Whaley KJ, McKinley SA, Fischer WA, Harit D, Lai SK (2018) ZMapp reinforces the airway mucosal barrier against ebola virus. J Infect Dis 218:901-910. https://doi. org/10.1093/infdis/jiy230

Ye J, Shao H, Hickman D, Angel M, Xu K, Cai Y, Song H, Fouchier RAM, Qin A, Perez DR (2010) Intranasal delivery of an IgA monoclonal antibody effective against sublethal H5N1 influenza virus infection in mice. Clin Vaccine Immunol 17:1363-1370. https://doi.org/10.1128/CVI.00002-10

Yuan S, Hollinger M, Lachowicz-Scroggins ME, Kerr SC, Dunican EM, Daniel BM, Ghosh S, Erzurum SC, Willard B, Hazen SL, Huang X, Carrington SD, Oscarson S, Fahy JV (2015) Oxidation increases mucin polymer cross-links to stiffen airway mucus gels. Sci Transl Med 7:276ra27. https://doi.org/10.1126/scitranslmed. 3010525

Zhang H, Yang Z, Xiang J, Cui Z, Liu J, Liu C (2020) Intranasal administration of SARS-CoV-2 neutralizing human antibody prevents infection in mice. Bioengineering

Zierenberg B (1999) Optimizing the in vitro performance of Respimat. J Aerosol Med 12(Suppl 1):S19-24. https://doi.org/10.1089/jam. 1999.12.suppl_1.s-19

Publisher's note Springer Nature remains neutral with regard to jurisdictional claims in published maps and institutional affiliations. 